\title{
Designing a suite of measurements to understand the critical zone
}

\author{
Susan L. Brantley ${ }^{1}$, Roman A. DiBiase ${ }^{1}$, Tess A. Russo ${ }^{1}$, Yuning Shi ${ }^{2}$, Henry Lin ${ }^{2}$, Kenneth J. Davis ${ }^{3}$, \\ Margot Kaye $^{2}$, Lillian Hill ${ }^{2}$, Jason Kaye ${ }^{2}$, David M. Eissenstat ${ }^{2}$, Beth Hoagland ${ }^{1}$, Ashlee L. Dere ${ }^{1, a}$, \\ Andrew L. Neal ${ }^{4}$, Kristen M. Brubaker ${ }^{5}$, and Dan K. Arthur ${ }^{4}$ \\ ${ }^{1}$ Earth and Environmental Systems Institute and Department of Geosciences, \\ Pennsylvania State University, PA, USA \\ ${ }^{2}$ Department of Ecosystem Science and Management, Pennsylvania State University, PA, USA \\ ${ }^{3}$ Earth and Environmental Systems Institute and Department of Meteorology, \\ Pennsylvania State University, PA, USA \\ ${ }^{4}$ Earth and Environmental Systems Institute, Pennsylvania State University, PA, USA \\ ${ }^{5}$ Department of Environmental Studies, Hobart and William Smith Colleges, NY, USA \\ ${ }^{a}$ now at: Department of Geography and Geology, University of Nebraska Omaha, NE, USA
}

Correspondence to: Susan L. Brantley (sxb7@psu.edu)

Received: 21 July 2015 - Published in Earth Surf. Dynam. Discuss.: 17 September 2015

Revised: 27 January 2016 - Accepted: 9 February 2016 - Published: 4 March 2016

Abstract. Many scientists have begun to refer to the earth surface environment from the upper canopy to the depths of bedrock as the critical zone (CZ). Identification of the $\mathrm{CZ}$ as an integral object worthy of study implicitly posits that the study of the whole earth surface will provide benefits that do not arise when studying the individual parts. To study the $\mathrm{CZ}$, however, requires prioritizing among the measurements that can be made and we do not generally agree on the priorities. Currently, the Susquehanna Shale Hills Critical Zone Observatory (SSHCZO) is expanding from a small original focus area $\left(0.08 \mathrm{~km}^{2}\right.$, Shale Hills catchment), to a larger watershed $\left(164 \mathrm{~km}^{2}\right.$, Shavers Creek watershed) and is grappling with the prioritization. This effort is an expansion from a monolithologic first-order forested catchment to a watershed that encompasses several lithologies (shale, sandstone, limestone) and land use types (forest, agriculture). The goal of the project remains the same: to understand water, energy, gas, solute, and sediment (WEGSS) fluxes that are occurring today in the context of the record of those fluxes over geologic time as recorded in soil profiles, the sedimentary record, and landscape morphology.

Given the small size of the Shale Hills catchment, the original design incorporated measurement of as many parameters as possible at high temporal and spatial density. In the larger Shavers Creek watershed, however, we must focus the measurements. We describe a strategy of data collection and modeling based on a geomorphological and land use framework that builds on the hillslope as the basic unit. Interpolation and extrapolation beyond specific sites relies on geophysical surveying, remote sensing, geomorphic analysis, the study of natural integrators such as streams, groundwaters or air, and application of a suite of CZ models. We hypothesize that measurements of a few important variables at strategic locations within a geomorphological framework will allow development of predictive models of $\mathrm{CZ}$ behavior. In turn, the measurements and models will reveal how the larger watershed will respond to perturbations both now and into the future. 


\section{Introduction}

The critical zone $(\mathrm{CZ})$ is changing due to human impacts over large regions of the globe at rates that are geologically significant (Vitousek et al., 1997a, b; Crutzen, 2002; Wilkinson and McElroy, 2007). To maintain a sustainable environment requires that we learn to project the future of the $\mathrm{CZ}$. Models are therefore needed that accurately describe $\mathrm{CZ}$ processes and that can be used to project, or "earthcast", the future using scenarios of human behavior. At present we cannot earthcast all the properties of the $\mathrm{CZ}$ but rather must model individual processes (Godderis and Brantley, 2014). Even so, many of our models are inadequate to make successful estimates of first-order CZ behavior today, let alone projections for tomorrow. For example, we cannot a priori estimate streamflow even if we know the climate conditions, soil properties, and vegetation in a given catchment because of difficulties in characterizing how much water is lost to evapotranspiration and to groundwater (Beven, 2011). Likewise, we cannot a priori estimate the depth or chemistry of regolith on a hillslope even if we know its lithology and tectonic and climatic history because we do not adequately understand what controls the rates of regolith formation and transport (Amundson, 2004; Brantley and Lebedeva, 2011; Dietrich et al., 2003; Minasny et al., 2008). Perhaps even more unexpectedly, we often do not even agree upon which minimum measurements are needed to answer these questions at any location.

Such difficulties are largely due to two factors: (i) we cannot adequately quantify spatial heterogeneities and temporal variations in the reservoirs and fluxes of water, energy, gas, solutes, and sediment (WEGSS); and (ii) we do not adequately understand the interactions and feedbacks among chemical, physical, and biological processes in the $\mathrm{CZ}$ that control these fluxes. This latter problem reflects the fact that the CZ (Fig. 1) is characterized by tight coupling between chemical, physical, and biological processes that exert both positive and negative feedbacks on surface processes. Modeling the $\mathrm{CZ}$ is fraught with problems precisely because of these feedbacks and because the presence of thresholds means that extrapolation from sparse measurements is challenging (Chadwick and Chorover, 2001; Ewing et al., 2006).

However, the result of these couplings and feedbacks is that patterns of measurable properties emerge during evolution of critical zone systems that are repeated from site to site despite variations in environmental conditions. Such patterns include the distributions across landscapes or versus depth of such observables as regolith, fractures, bacterial species, or gas composition. Gradients in some important observable properties (e.g., surface elevation, chemistry of water, and regolith composition) emerge as indicators of the evolution of the $\mathrm{CZ}$ and reveal aspects of the underlying complex behavior (brown boxes, Fig. 1). For systems experiencing negative feedbacks, such gradients are thought to move toward steady-state conditions, i.e., gradients that remain constant over some interval of time.

In Fig. 1, some of these important gradients are arrayed from left to right to indicate the increasing length of time it takes for each gradient in general to achieve such a steady state. In other words, a steady-state soil gas depth profile might develop more rapidly than a steady-state regolith chemistry depth profile. Different disciplines tend to focus on different emergent properties (for example, different gradients) and thus tend to emphasize processes operating on disparate timescales. However, $\mathrm{CZ}$ science is built upon the hypothesis that an investigation of the entire object - the $\mathrm{CZ}$ - across all timescales under transient and steady-state conditions (Fig. 1) will yield insights that disciplinary-specific investigations cannot. In turn, such integrative study and modeling should allow a deeper understanding of the patterns that characterize the $\mathrm{CZ}$.

Given that the mechanisms driving $\mathrm{CZ}$ change range from tectonic forcing over millions of years to glacial-interglacial climate change over thousands of years to the recent influence of humans on the landscape, building a model of the $\mathrm{CZ}$ is daunting, and no single model has been developed. Instead, suites or cascades of simulation models have been used to address important processes over different timescales (e.g., Godderis and Brantley, 2014). To enable treatment using such a suite of models, each setting for $\mathrm{CZ}$ research, including CZ observatories (CZOs; White et al., 2015), must grapple with the necessity of measuring the processes on different timescales to understand the dynamics and evolution of the system.

At the Susquehanna Shale Hills CZO (SSHCZO), we have been investigating this challenge by studying the $\mathrm{CZ}$ in a $0.08 \mathrm{~km}^{2}$ watershed located in central Pennsylvania (the Shale Hills catchment; Fig. 2). At the same time, we have been developing a suite of models that can be interconnected to address broad overarching CZ problems (Duffy et al., 2014; Table 1). The focus of the effort has been the small Shale Hills catchment, which was established for hydrologic research in the 1970s (Lynch, 1976) and was expanded with other disciplinary studies as a CZO in 2007 as part of a network of CZOs in the USA. The small spatial scale of Shale Hills allowed the development of a diverse but dense monitoring network that spans disciplines from meteorology to groundwater chemistry to landscape evolution (Fig. 2). Given the small size, we referred to our measurement paradigm as "measure everything, everywhere". For example, we inventoried all of the $\sim 2000$ trees with a diameter greater than $20 \mathrm{~cm}$ at breast height, drilled 28 wells (up to $50 \mathrm{~m}$ deep), sampled soil pore waters at 13 locations at multiple depths approximately every other week during the non-snow-covered seasons for more than 1 year, and measured soil moisture at 105 locations (Fig. 2).

The approach at Shale Hills has been to develop understanding incrementally by studying CZ systems of increasing complexity. The catchment itself is situated on a sin- 


\section{A conceptual model of the $\mathrm{CZ}$}

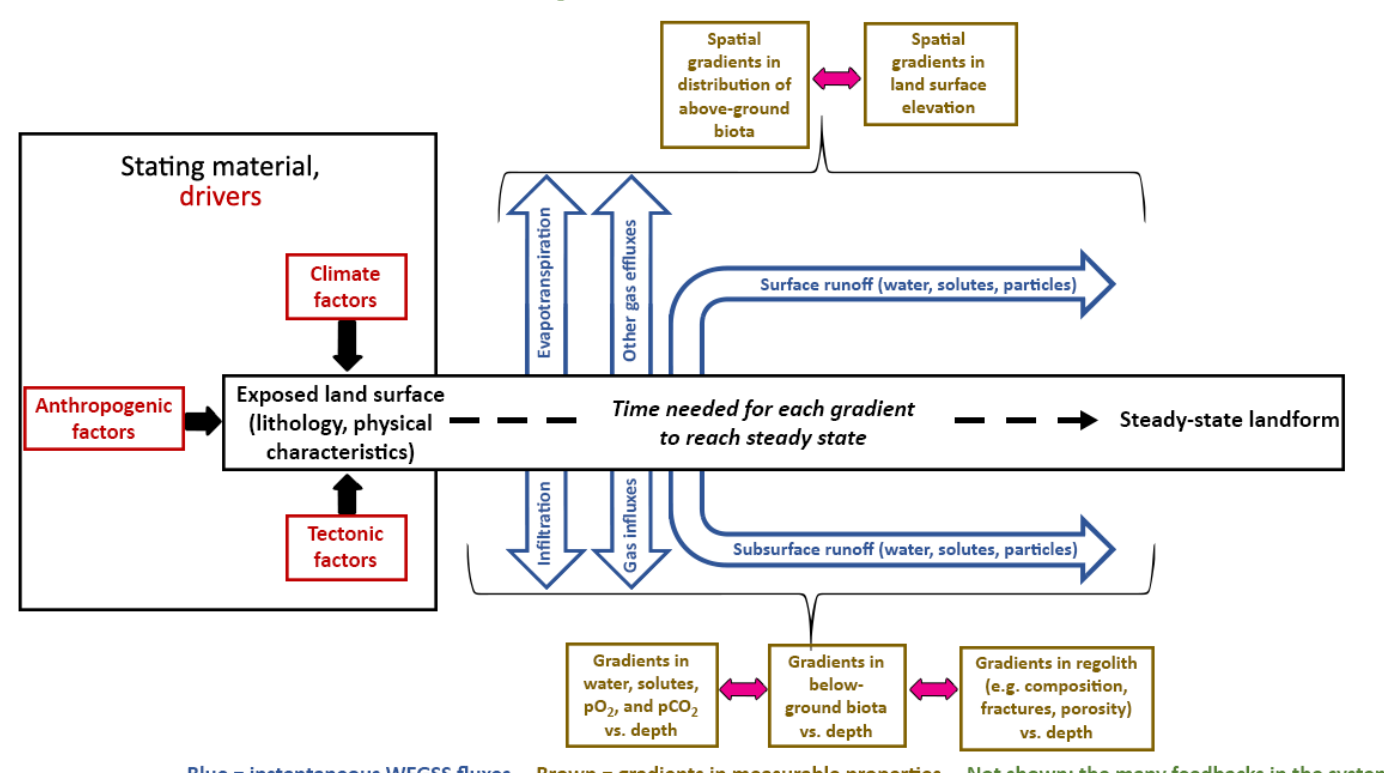

Figure 1. Critical zone science investigates the architecture, character, and dynamics of the earth surface from vegetation canopy to deep groundwater on all timescales. As rock of a certain lithology and structural character is exposed at the earth's surface due to uplift or erosion, climate-driven inputs transform it to regolith. This transformation, shown in the black box, is catalyzed by biota (a feedback which is not shown explicitly). Gradients of properties describing the $\mathrm{CZ}$ are shown in brown boxes. These gradients can become time-independent (steady state) due to the many feedbacks which are not shown. Boxes are placed from left to right to note the increasing duration of exposure time needed to achieve such steady states. For example, depth profiles of regolith composition can become constant when the rate of erosion equals the rate of weathering advance in the presence of feedbacks related to pore water chemistry, soil gas composition, and grain size. The figure emphasizes that gradients to the left can achieve steady state quickly compared to properties to the right. Therefore, properties to the left are often studied as if the properties in boxes to the right are constant boundary conditions. However, over the longest timescales, all properties vary and can affect one another. The complexity of feedbacks (which are not shown for simplicity) can also create thresholds in system behavior. Red boxes indicate drivers and blue arrows are WEGSS fluxes (upward arrows for aboveground and downward arrows for belowground).

Table 1. Designing a suite of CZ models. PIHM: Penn State Integrated Hydrologic Model; LE-PIHM: PIHM with landscape evolution module; Regolith-RT-PIHM: PIHM with regolith formation and reactive transport modules; CARAIB: CARbon Assimilation In the Biosphere; ED2: Ecosystem Demography model; Flux-PIHM-BGC: PIHM with surface heat flux and biogeochemistry modules; PIHM-SED: PIHM with sediment transport module; RT-Flux-PIHM: PIHM with surface heat flux and reactive transport modules; Flux-PIHM: PIHM with surface heat flux module.

\begin{tabular}{|c|c|c|c|}
\hline & Modeling purpose & Model & Timescale of interest \\
\hline \multirow{8}{*}{$\begin{array}{l}\text { Numerical models in use } \\
\text { at SSHCZO }\end{array}$} & Topography (landscape evolution) & LE-PIHM & Days-millions of years \\
\hline & Regolith composition and structure & Regolith-RT-PIHM, WITCH ${ }^{\mathrm{a}}$ & Hours-millions of years \\
\hline & Distribution of biota & $\mathrm{BIOME}^{\mathrm{b}}, \mathrm{CARAIB}^{\mathrm{c}}, \mathrm{ED} 2$ & Days-centuries \\
\hline & $\mathrm{C}$ and $\mathrm{N}$ pools and fluxes & Flux-PIHM-BGC & Days-decades \\
\hline & Sediment fluxes & PIHM-SED & Hours-decades \\
\hline & Solute chemistry and fluxes & RT-Flux-PIHM ${ }^{\mathrm{d}}$, WITCH & Hours-decades \\
\hline & Soil $\mathrm{CO}_{2}$ concentration and fluxes & CARAIB & Hours-decades \\
\hline & Energy and hydrologic fluxes & 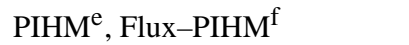 & Hours-decades \\
\hline
\end{tabular}

\begin{tabular}{ll}
\hline Geological factor & $\begin{array}{l}\text { Uplift rate, bedrock composition, bedrock physical properties, preexisting geological } \\
\text { factors such as glaciation }\end{array}$ \\
\hline External driver & $\begin{array}{l}\text { Energy inputs, chemistry of wet and dry deposition, atmospheric composition, climate conditions, } \\
\text { anthropogenic activities }\end{array}$
\end{tabular}

${ }^{\mathrm{a}}$ Godderis et al. (2006); ${ }^{\mathrm{b}}$ Kaplan et al. (2003); ${ }^{\mathrm{c}}$ Warnant et al. (1994); ${ }^{\mathrm{d}}$ Bao et al. (2016); ${ }^{\mathrm{e}}$ Qu and Duffy (2007); ${ }^{\mathrm{f}}$ Shi et al. (2013). 


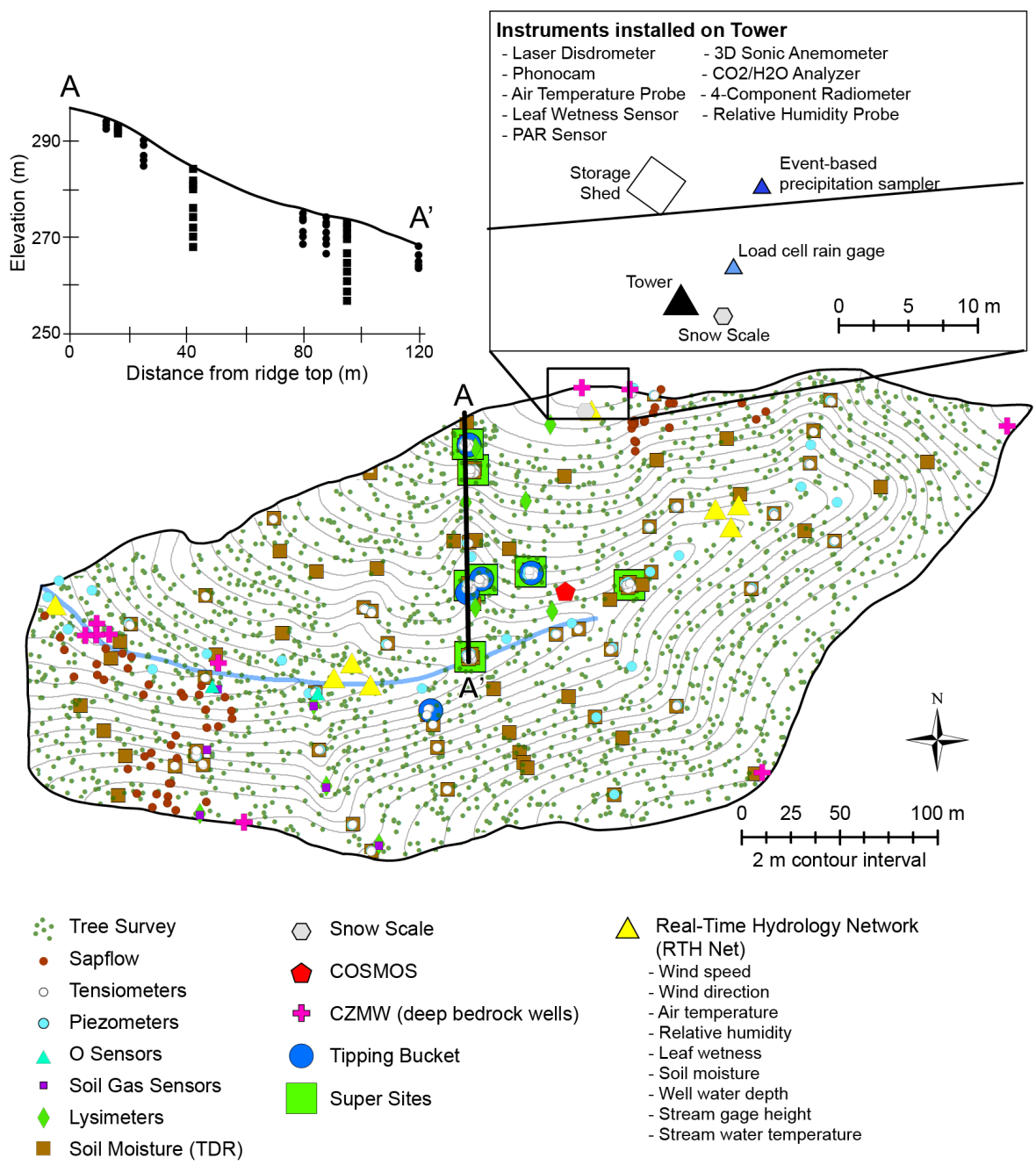

Figure 2. Mapped summary of the "everything, everywhere" sampling strategy at the Shale Hills subcatchment. Insets show soil moisture sensors (circles) and lysimeters (squares) along the transect shown on the map. Sensor and lysimeter depths are exaggerated 5 times compared to the land surface elevation. Second inset shows instrumentation deployed at the meteorological station on the northern ridge. Small green dots on the map are the trees that were surveyed and numbered: the subcatchment contains a dry oak-mixed hardwood community type (Fike, 1999) with an extremely diverse mix of hardwood and softwood species, including white oak (Quercus alba), sugar maple (Acer saccharum), pignut hickory (Carya glabra), eastern hemlock (Tsuga canadensis), and chestnut oak ( $Q$. montana). The sparse understory consists of American hop hornbeam (Ostrya virginiana) and serviceberry (Amelanchier spp.). As we upscale the CZO to all of Shavers Creek, many measurements will be eliminated in the Shale Hills subcatchment as we emphasize only a Ground HOG and Tower HOG deployment as described for the Garner Run subcatchment.

gle lithology (shale), which simplified the boundary conditions for models with respect to initial chemical and physical conditions. We have monitored at ridgetops (where water and soil transport is approximately 1-D), along planar hillslopes (transects where such transport is essentially 2-D), and within swales and the full catchment (where transport must be considered in full 3-D). Where possible, these observations have then been paired with 1-D, 2-D, and 3-D model simulations. Using the conceptualization of 1-D, 2-D, and 3D settings in the catchment has allowed measurements and modeling to proceed in a synergistic fashion: the reduction in complexity in 1-D and 2-D sites enabled development of models but also focused our sampling schemes. For example, our model conceptualizations of soil formation were developed first for ridgetops (1-D) and then for planar (2-D) hillslope systems and have been highly influenced by our soil chemistry measurements on ridgetops and planar hillslope catenas (Jin et al., 2010; Lebedeva and Brantley, 2013; West et al., 2013; Ma et al., 2013). In some cases modeling and measurement proceed hand in hand, while in others, the modeling lags behind. For example, soil measurements have been collected in hillslopes characterized by convergent water and soil flow regimes, i.e., swales (Jin and Brantley, 2011), and soil observations have been collected across much 
of the catchment, but soil formation models for swales or the entire catchment still remain to be developed.

In contrast to the soil formation models that have targeted the 1-D and 2-D sites, our models of water flow have been developed for the entire catchment (e.g., Qu and Duffy, 2007). In fact, study of an entire catchment with a hydrologic model is sometimes more tractable than for smaller sub-systems because the large-scale study allows a continuum treatment, whereas treatment of smaller-scale sub-systems within the catchment might require measurements of the exact positions of heterogeneities such as fractures, faults, and lowpermeability zones.

The goal of the SSHCZO project now is to grapple with some of these down- and upscaling issues by expanding the CZO from Shale Hills to the encompassing $164 \mathrm{~km}^{2}$ Shavers Creek watershed (Fig. 3). The expansion was designed to allow the investigation of a broader range of lithology (sandstone, calcareous shale, minor limestone) and land use (agriculture, managed forest, minor development), and to test models on larger spatial scales. To enable understanding of the larger watershed, we chose to analyze a suite of smaller subcatchments in detail, each of which were selected to be the largest that still drain a single rock unit or land use type. This allows evaluation of how much of our understanding from Shale Hills is transferable to other lithologies with different initial conditions but with the same climate. Additionally, we are making targeted measurements of the main stem of Shavers Creek in nested catchments of differing size within the larger watershed, in order to upscale our sitespecific models to a relatively complex watershed.

Despite its small size, Shavers Creek contains much of the variability in $\mathrm{CZ}$ parameter space found within the Susquehanna River basin and the Appalachian Valley and Ridge province in general. By measuring in detail paired catchments of similar size but different underlying conditions, along with targeted measurements in nested catchments of differing size, we aim to test theories of $\mathrm{CZ}$ evolution, parameterize models (Table 1) in different settings, and explore approaches toward upscaling across different size watersheds.

To understand the interaction of WEGSS fluxes in Shavers Creek and its smaller subcatchments, it is necessary to move beyond the paradigm of measuring everything, everywhere (Fig. 2) to an approach of measuring "only what is needed". This phrasing, although simplistic, should resonate with any field scientist: the choice of measurement design is at the heart of any field project. But when we study the $\mathrm{CZ}$ as a whole, we are asking how one allocates resources to measure and model the dynamics and evolution of the entire CZ system. This paper describes our philosophy of measurement in the $\mathrm{CZO}$; our previous paper describes the modeling approach (Duffy et al., 2014). Obviously, due to the wide range of CZ processes across environmental gradients (Fig. 1), the specifics of our proposed sampling design will differ from such designs at other sites. We nonetheless describe the philosophy behind our approach to stimulate focus on the broad question: how can we adequately and efficiently measure the entire $\mathrm{CZ}$ to best learn about its evolution and function? To exemplify our design, we also describe the first part of our expansion from Shale Hills to a sandstone subcatchment within Shavers Creek.

\section{Connections between model development and field measurements}

The suite of models shown in Table 1 is designed to develop understanding over the entire $\mathrm{CZ}$ as an integral object of study, i.e., one system. Field measurements are prioritized and driven by data needs for developing models (e.g., Table 1) and model development is dictated by observations in the field. Hand in hand with this system-level approach, researchers from different disciplines also bring disciplinespecific hypotheses to their research that are related to disciplinary gaps in knowledge. Thus, disciplinary-level hypotheses also drive $\mathrm{CZO}$ research and sometimes these hypotheses feed directly into the overall $\mathrm{CZ}$ suite of models. Furthermore, because our understanding of the complicated suite of $\mathrm{CZ}$ processes is still in its infancy, both baseline measurements and curiosity-driven sample collection are still vital to determine the important processes. Throughout, models and observations are allowed to evolve to enable the two-way exchange of insights needed to maximize $\mathrm{CZ}$ science.

Given all the needs for data, the sampling plan which is implemented in a $\mathrm{CZO}$ must provide both measurements to test disciplinary hypotheses and observations necessary to bridge across disciplines. Additionally, certain measurements such as geophysical and remote sensing surveys, catchment-integrating stream measurements, and timeintegrating analysis of alluvial and colluvial sediments can be made along with model simulations to upscale across space (from limited-point or subregion measurements to the whole watershed) and time (from limited temporal measurements to geological timescales).

Perhaps the largest difficulty in spatially characterizing the $\mathrm{CZ}$ in any observatory is the assessment of the extremely heterogeneous subsurface and land surface, ranging from the assessment of regolith and pore fluids down to bedrock to variations in land use. Because the mixing timescales of biota, regolith, and bedrock are relatively slow (compared to mixing of atmospheric and surface water reservoirs), the assessment of the spatial distribution of biota, regolith, and bedrock properties is both important and extremely challenging (Niu et al., 2014). On the other hand, rapid changes in the atmospheric reservoir make robust atmospheric measurements technically difficult. The hydrologic state is intermediate, exhibiting large spatial and temporal variability.

In recognition of these difficulties, the project started at Shale Hills precisely because it is a catchment almost $100 \%$ underlain by Rose Hill formation shale and strictly managed as forestland. Surface heterogeneities at Shale Hills 


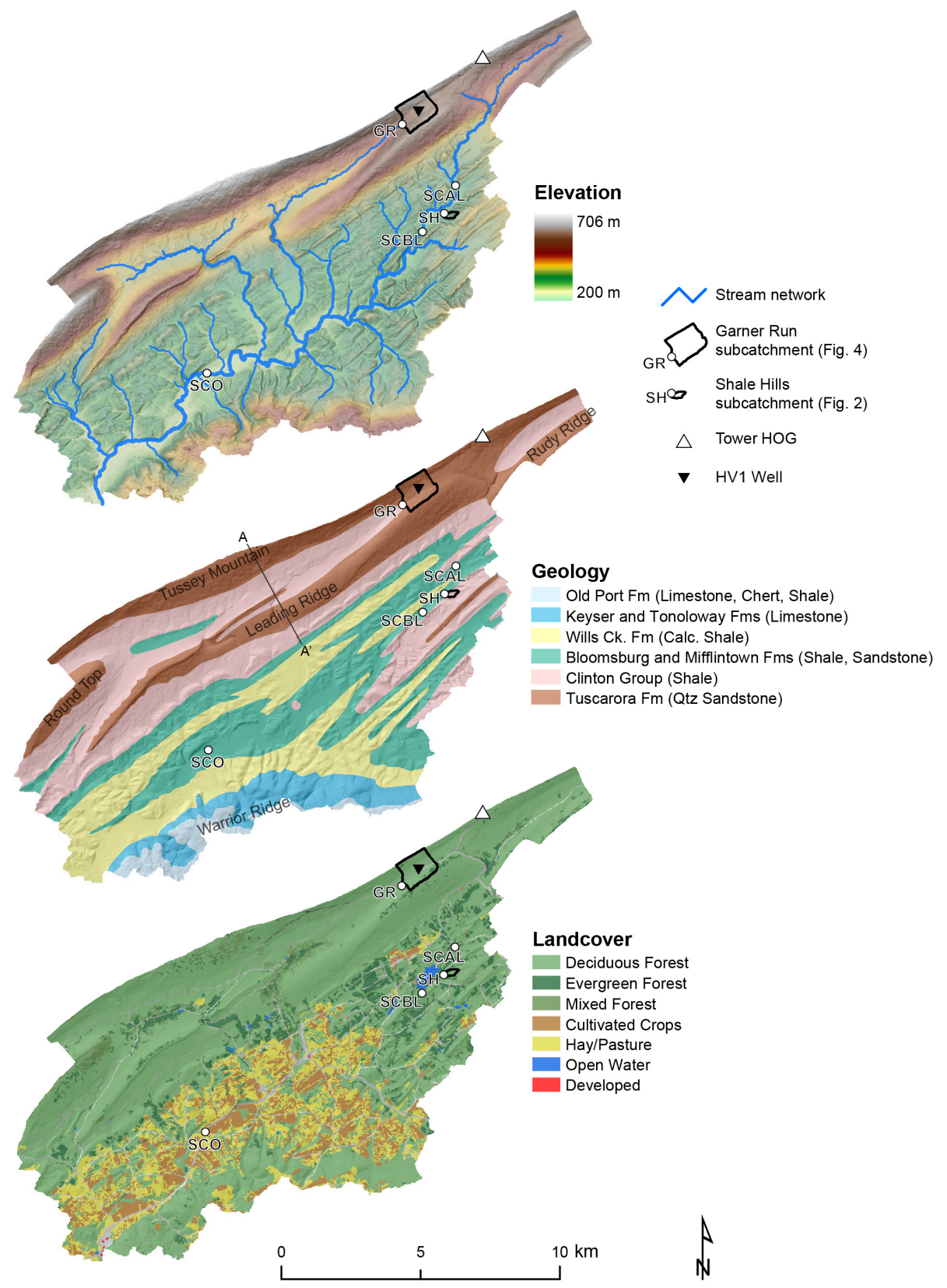

Figure 3. Map of Shavers Creek watershed, highlighting (a) topography derived from airborne lidar, (b) geology (Berg et al., 1980), and (c) land use (Homer et al., 2015). In moving from "measure everything everywhere" (our paradigm in the 8 ha Shale Hills catchment; SH) to "measure only what is needed" in the Shavers Creek watershed $\left(164 \mathrm{~km}^{2}\right)$, we chose to investigate two new first-order subcatchments: a forested sandstone site (along Garner Run, marked GR) and an agricultural calcareous shale site (to be determined). In addition, three sites on Shavers Creek have been chosen as stream discharge and chemistry monitoring sites (marked SCAL - Shavers Creek above lake; SCBL - Shavers Creek below lake; and SCO - Shavers Creek outlet). Location of Fig. 4 is indicated by cross section A-A'.

were largely related to hillslope position, colluvium related to the Last Glacial Maximum (LGM), fracturing, differences in sedimentary layers, and relatively limited spatial variations in vegetation. To understand the $\mathrm{CZ}$ at the Shavers Creek watershed, on the other hand, we must grapple with a more complex set of variations related to differences in lithology, land use, climate change, and landscape adjustment to changes in base level due to tectonics, eustasy, or stream capture (Fig. 3). Here, the term base level refers to the reference level or elevation down to which the watershed is currently being eroded.

In recognition of the new complexities within Shavers Creek, the sampling strategy was designed not to be ran- 
dom but rather to be stratified based on geological and geomorphological knowledge. An implicit hypothesis underlying this approach is the idea that sampling can be more limited for a stratified approach based on geological (especially geomorphological) knowledge. For example, a first-order observation about hillslope morphology in Shale Hills based on long-standing observations from hillslope geomorphology is the delineation between planar slopes and swales: the former experience largely 2-D nonconvergent flow, while the latter experience 3-D convergent flow of water and soil. Where many randomly chosen soil pits might be necessary if the delineation of swales versus planar hillslopes was ignored, when representative pits are dug to investigate these features separately, the number of pits can be minimized.

Another aspect of our stratified sampling plan is to complement measurements at Shale Hills by targeted measurements in two new subcatchments of Shavers Creek chosen to represent two of the new lithologies in the watershed. Once again the stratification of the sampling design is dictated by geological knowledge: bedrock geology is known to exert a first-order control on WEGSS fluxes in the CZ (e.g., Duvall et al., 2004; Williard et al., 2005). The first such new subcatchment is forested and underlain only by sandstone. The second subcatchment for targeted measurements is currently being identified on calcareous shale. This second subcatchment will also host several farms and will allow the assessment of the effects of this land use on WEGSS fluxes.

To upscale from subcatchments to Shavers Creek, the targeted subcatchment data will be amplified by measurements of chemistry and streamflow along the main stem of Shavers Creek as well as catchment-wide meteorological measurements (Fig. 3). The upscaling will rely on the small number of sites chosen for soil, vegetation, pore-fluid, and soil gas measurements in each subcatchment. To extrapolate from and interpolate between these limited land surface measurements, models of landscape evolution (LE-PIHM), soil development (e.g., Regolith-RT-PIHM, WITCH), distribution of biota (BIOME4, CARAIB), $\mathrm{C}$ and $\mathrm{N}$ cycling (Flux-PIHM-BGC), sediment fluxes (PIHM-SED), solute fluxes (RT-Flux-PIHM, WITCH), soil gases (CARAIB), and energy and hydrologic fluxes (PIHM, Flux-PIHM) will be used. In effect, the plan is to substitute everything everywhere with measurements of only what is needed by using (i) integrative measurements (geophysics, lidar, stream, atmosphere), and (ii) models of the CZ. As a simple example, a regolith formation model is under development that will predict distributions of soil thickness on a given lithology under a set of boundary conditions. Since much of the water flowing through the upland catchments under study in the CZO flows as interflow through the soil and upper fractured zone (Sullivan et al., 2016), use of the regolith formation model will enable better predictions of the distribution of permeability. Of course, the models will be continually groundtruthed against pinpointed field measurements.
With this approach, water fluxes in the subcatchments and in Shavers Creek watershed itself will eventually be estimated.

For clarity in describing the measurements in each subcatchment that are needed for the models, we have given names to arrays of instruments (Table S1 in the Supplement). The array of instruments in soil pits $(1 \mathrm{~m} \times 1 \mathrm{~m} \times \sim 2 \mathrm{~m}$ deep) and in trees near the pits along a catena is referred to as ground hydrological observation gear (Ground HOG). The Ground HOG deployments also are the locations for assessments of vegetation across transects. Geophysical surveys and geomorphic analysis using lidar are conducted to interpolate between or extrapolate beyond the catenas.

In addition to Ground HOG, the energy, water, and carbon fluxes are measured using tower hydrologic observation gear (Tower HOG). Ground and Tower HOGs are in turn accompanied by measurements of chemistry and temperature of stream and groundwater, as well as discharge and water level for stream and groundwater, respectively. As discussed above, these streams and groundwaters provide natural spatial and temporal integrations over the watershed and therefore provide constraints on the 3-D-upscaled models.

Data from Ground HOG and Tower HOG will be used to parameterize and constrain model-data comparison and data assimilation. In fact, the choice of targeted measurements is derived at least in part from an observational system simulation experiment (OSSE) completed for the Shale Hills catchment using the Flux-PIHM model (Table 1) (Shi et al., 2014b). The OSSE evaluates how well a given observational array describes the state variables that are targeted by Flux-PIHM. Specifically, this OSSE (Shi et al., 2014b) emphasized water and energy fluxes for the catchment.

Prior to the OSSE, a sensitivity analysis was performed (Shi et al., 2014a) to determine the six most influential model parameters that were needed to constrain and produce a successful simulation. We defined "successful simulation" as one that reproduced the temporal variations of the four land surface hydrologic fluxes (stream discharge, sensible heat flux, latent heat flux, and canopy transpiration) and the three state variables (soil moisture, water table depth, and surface brightness temperature) (Table 1) with high correlation coefficients and small root mean square errors. Once the six most influential model parameters were determined - porosity, van Genuchten parameters $\alpha$ and $\beta$, Zilitinkevich parameters, minimum stomatal resistance, and canopy water storage - the OSSE was then performed.

The OSSE evaluated which of the fluxes and state variables were most important in constraining those model parameters. Shi et al. (2014b) found that the calibration coefficients for the most important model parameters were most sensitive to observations of (i) stream discharge, (ii) soil moisture, and (iii) surface brightness temperature. (Alternatively, instead of brightness temperature, measurements could focus on sensible and latent heat fluxes.) The OSSE has also been validated with assimilation of field observations at Shale Hills (Shi et al., 2015b). 
On the basis of this OSSE, we are targeting measurement of stream discharge, soil moisture, and surface brightness temperature for each of the SSHCZO subcatchments on shale, sandstone, and calcareous shale. These measurements should allow us to reproduce subcatchmentaveraged land-atmosphere fluxes and subsurface hydrology adequately. Once the three subcatchments are parameterized, the models will then be upscaled to the entire Shavers Creek watershed using information from lidar, the Natural Resources Conservation Service Soil Survey Geographic database (SSURGO; http://www.nrcs.usda.gov/wps/ portal/nrcs/main/soils/survey/), geological maps, geophysical surveying, and land use.

Currently, the OSSE has only been used for assimilation of water and energy data but is being expanded to include biogeochemical variables. We also aim to complete an OSSE for $\mathrm{C}$ and $\mathrm{N}$ fluxes in each subcatchment. In the long run, we could also extend the OSSE to assimilate data for other solutes and for sediments.

Modeling results from Shale Hills indicated that an accurate simulation of the subcatchment spatial patterns in soil moisture was achieved using a relatively limited set of hydrologic measurements made at a few points (Shi et al., 2015a). Specifically, we had to measure (i) stream discharge at the outlet, (ii) soil moisture at a few locations, and (iii) groundwater levels at a few locations. The soil moisture (ii) and groundwater (iii) data used to calibrate the model were from three nearly colocated sites in the valley floor. These realtime hydrology network sites (referred to as RTHnet in Fig. 2) were the only sites with continuous data at the time of model calibration (data from the Cosmic-ray Soil Moisture Observing System (COSMOS)) were not yet available). The measurements were averaged across the three RTHnet sites (see data posted at http://criticalzone.org/shale-hills/ data/dataset/3615/) to provide one calibration point in the model. Extending from this calibration point to the entire catchment was attempted using data from SSURGO. However, because of the coarse spatial data available in SSURGO, this was not successful for the very small Shale Hills catchment. Therefore, porosity, horizontal and vertical saturated hydraulic conductivity, and the van Genuchten parameters $\alpha$ and $\beta$ were separately measured for each soil series and then were averaged for the whole soil column for each soil series (Table S2). These soil core measurements for each soil series were used to constrain the shape of the soil water retention curve for each soil series in the model.

The result of this effort was that for the monolithologic $0.08 \mathrm{~km}^{2}$ catchment of Shale Hills, five soil series were identified and soil properties measured (Lin et al., 2006). As we proceed with work on the new subcatchments, one of two approaches will be used. First, it is possible that relatively few soil moisture measurement locations are required in any given catchment, as long as we can obtain soil hydraulic properties for each soil series. Using the SSURGO soils database, such measurements could be made to parame- terize the model. Alternatively, spatially extensive soil moisture measurements based on COSMOS may be adequate to infer the variations in soil hydraulic properties on a series-byseries basis or based on geomorphological criteria. The overall plan is to use (i) SSURGO, (ii) geomorphological constraints, (iii) COSMOS, and (iv) soil moisture measurements along the catenas to parameterize Flux-PIHM.

To the extent possible, we parameterize these PIHM models with data sets and then evaluate the models with different data sets. The phrase "data assimilation" conveys the idea, however, that with more and more complex models, the data and the model output become harder to distinguish. For example, the output calculated for a given observable from a complex model may be more accurate than any individual measurement of that observable. As model output is used to parameterize other models, such data assimilation obscures the difference between model and data. Considered in a different way, data assimilation provides a means to combine the strengths of both in situ observations and numerical models. Data assimilation can thus provide optimal estimates of observable variables and parameters, taking into account both the uncertainties of model predictions and observations.

As new types of observations are provided, we first evaluate PIHM model output against the new observations prior to calibrations to see if the current calibration predicts the new data. This comparison is ongoing for the Garner Run subcatchment. If the prediction is poor, this yields insight into the capabilities of our model under new conditions. If we discover that even with a new calibration we cannot successfully predict the new observations, we will incorporate a new module that describes a new phenomenon in PIHM. For example, discrepancies between model output and preliminary observations at Garner Run have led us to hypothesize that the distribution of boulders on the land surface - a phenomenon not observed in the Shale Hills catchment - must be incorporated into the PIHM models. By tracking which parameters must be tuned and which processes must be added, we gain insights into both the model and system dynamics, and we learn which parameters must be observed if we want to apply our model to a new site or a new time period.

\section{Implementation in the Garner Run subcatchment}

These discussions about the design of a sampling strategy can best be explained through examples. In this section we introduce the Garner Run subcatchment, one of the two new focus subcatchments planned within the Shavers Creek watershed. To exemplify the approach, we describe the setting and some preliminary observations and measurements from soil pits, vegetation surveys, and water monitoring. 


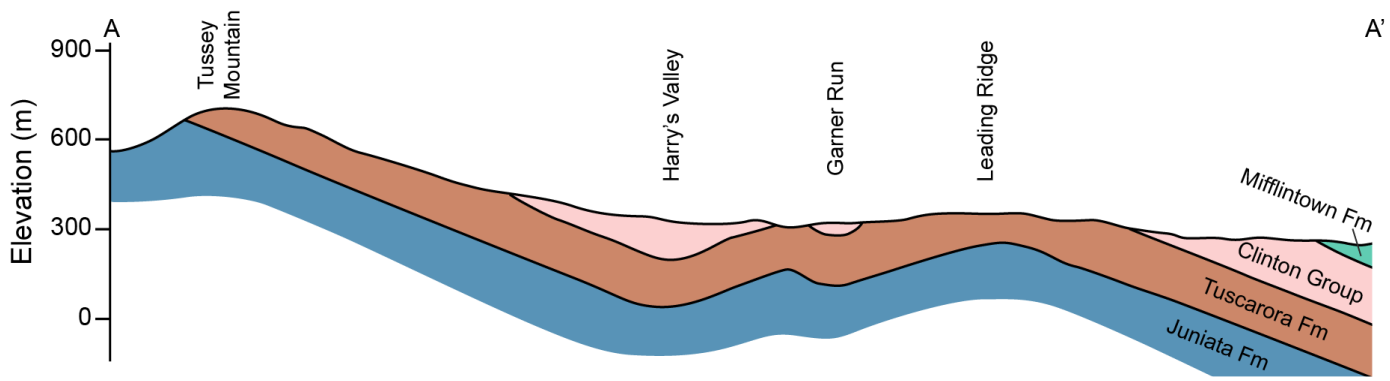

Figure 4. Geologic cross section of Garner Run subcatchment reproduced from Flueckinger (1969). Map units include Mifflintown (Middle Silurian), Clinton group (including Rose Hill formation), Tuscarora (Lower Silurian), and Juniata (Upper Ordovician). Cross section position is downstream from the Garner Run subcatchment (see Fig. 3) and locally preserves Clinton Group shales in the valley floor, overlying the Tuscarora Formation.

\subsection{Geologic, geomorphic, and land use context of Garner Run}

A central underlying hypothesis of SSHCZO work is that the use of geomorphological and land use analysis can inform sampling strategy so that measurements can be limited in number. Therefore, we start by describing the current knowledge of the geomorphological setting of the Garner Run subcatchment and land use. The subcatchment drains a synclinal valley underlain by the Silurian Tuscarora Formation between the NW-SE trending ridges of Tussey Mountain and Leading Ridge (Figs. 3-5). The Tuscarora Formation, which locally consists of nearly pure quartz sandstone with minor interbedded shales, is the ridge-forming unit that caps the highest topography in Shavers Creek watershed. The hillslopes of both Tussey Mountain and Leading Ridge are nearly dip slopes, i.e., the roughly planar hillslopes parallel the bedding in the sandstone (Figs. 4, 5). Indeed, subtle bedding planes can be observed in lidar-derived elevation data (Fig. 6b). The strong lithologic control on landscape form is manifested clearly in the high-resolution $(1 \mathrm{~m})$ bare-earth lidar topography.

The hillslope morphology of the Garner Run subcatchment also contrasts strikingly in several ways from that of Shale Hills. Most notably, the sandstone hillslopes of Tussey Mountain and Leading Ridge are nearly planar in map view: they have not been dissected with the streams and swales common in the shale topography of much of Shavers Creek (Fig. 6). Hillslopes underlain by the Tuscarora Formation are also nearly 10 times longer $(300-600 \mathrm{~m})$ than those underlain by other geologic units within Shavers Creek, including shales. In Shale Hills, for example, hillslopes are 50$100 \mathrm{~m}$ in length (Fig. 7). Furthermore, the hillslopes at Garner Run are less steep (mean slope: $12-17^{\circ}$ ) compared to those at Shale Hills (mean slope: $14-21^{\circ}$ ), despite having significantly stronger underlying bedrock.

The observation of steeper hillslopes in Shale Hills versus Garner Run is particularly curious given that both subcatchments are presumed to have experienced similar histories of climate and tectonism. If the two landscapes were in

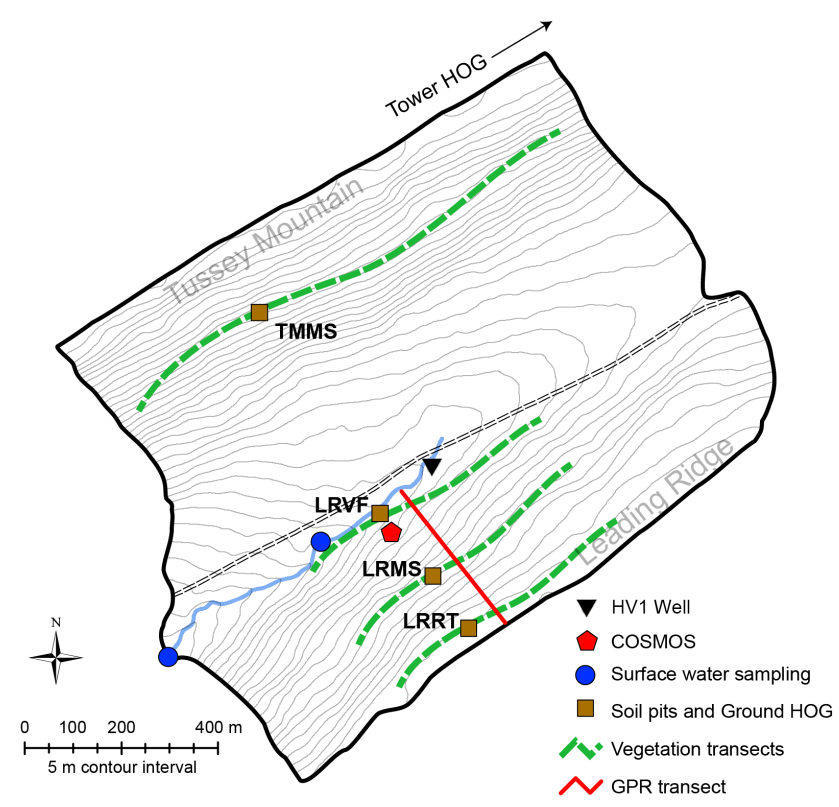

Figure 5. Map showing Garner Run subcatchment (blue line is the stream). Black dashed lines delineate Harry's Valley Road. The Harry's Valley well (HV1) is shown along with the location of the COSMOS unit and the outlet weir (blue dot to the southwest). The blue dot to the northeast indicates the approximate range of surface water sampling that is ongoing. Soil pits have been emplaced as shown, along with the Ground HOG deployment. Location of vegetation and ground-penetrating radar (GPR) transects reported in this paper are also shown. Tower HOG location is along the crest of Tussey Mountain to the northeast of the Garner Run subcatchment (Fig. 3).

a topographic steady state with the local erosion rate equal to the same regional rock uplift rate, we would expect that the sandstone would have evolved to generate steeper slopes. Thus, the shallower slopes on the resistant sandstone contradict the general idea that erosion and transport of more resistant bedrock that produces larger grain-size sediment generally requires steeper hillslopes. 


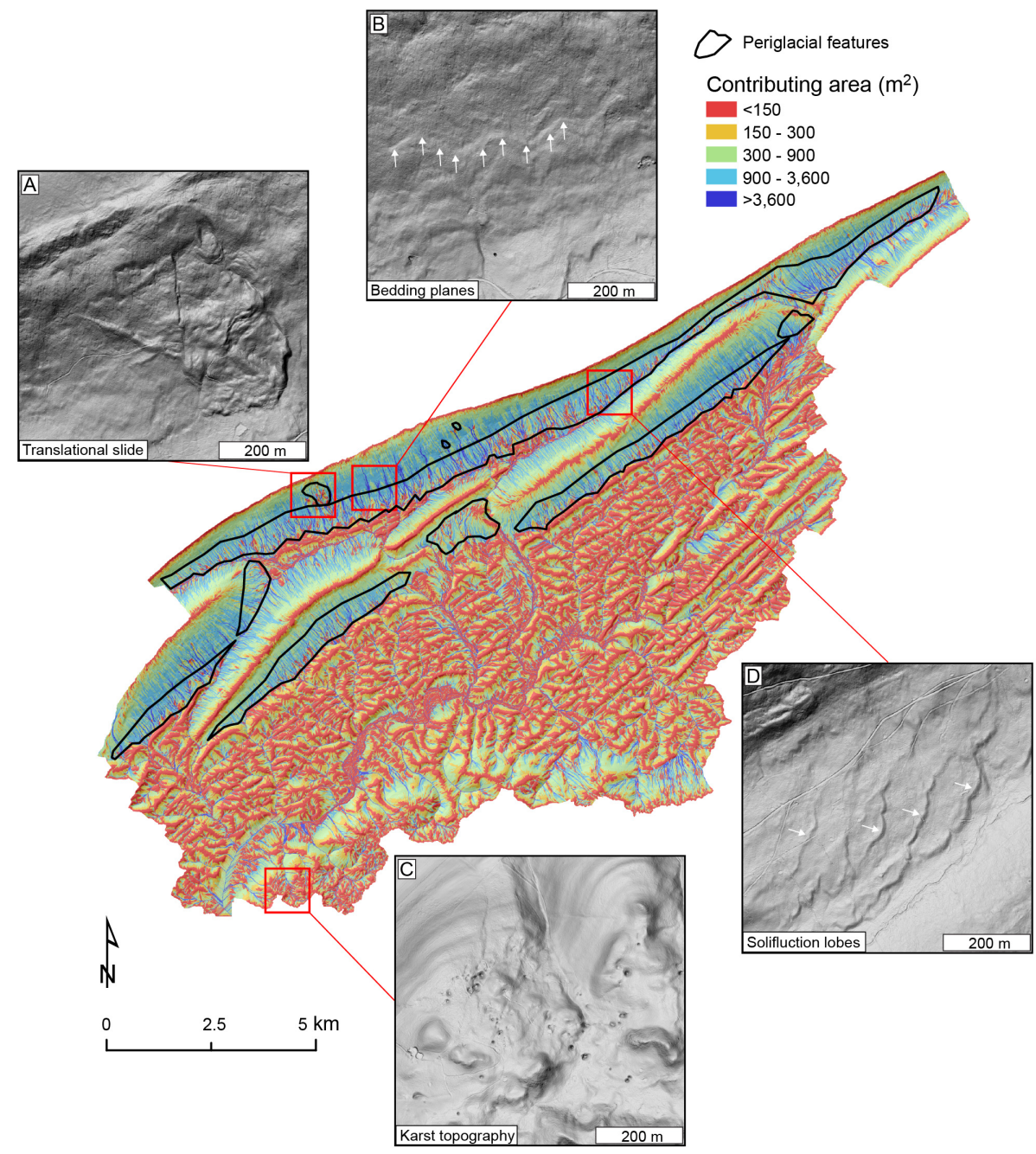

Figure 6. Map of bedrock and periglacial process controls on topography in Shavers Creek watershed. The contributing area was determined using the D-Infinity flow routing algorithm (Tarboton, 1997). The map highlights spatial variations in drainage density that correspond to sandstone (low drainage density and long hillslopes), shale (high drainage density and short hillslopes), and carbonate (intermediate drainage density and hillslope length) bedrock (see Fig. 4). Black outlines correspond to periglacial features expressed in the $1 \mathrm{~m}$ lidar topography, such as landslides (a) and solifluction lobes (d). Sandstone bedding planes (b) and limestone karst topography (c) are also prominent.

Two issues may explain this apparent contradiction. First, while the morphology of the Shale Hills catchment bears little resemblance to the underlying structure of steeply dipping shale beds, the topography of Garner Run is nearly entirely controlled by underlying Paleozoic structure (Fig. 4). Specifically, hillslope angles reflect dip slopes rather than morphodynamic equilibrium. Second, as a headwater stream in the Shavers Creek watershed, Garner Run is isolated from the regional base level controls that influence downstream catchments such as Shale Hills (Fig. 6).

Specifically, analysis of stream longitudinal profiles on Garner Run and the main stem of Shavers Creek reveals prominent knickpoints at elevations of $\sim 320$ and $380 \mathrm{~m}$, respectively (Fig. 7). Such breaks in channel slope geomorphically insulate the upper stream reaches from the main stem of Shavers Creek and could be consistent with different rates of local river incision into bedrock in the upper and lower reaches (e.g., Whipple et al., 2013). Published cosmogenic nuclide-derived bedrock lowering rates ranging from 5 to $10 \mathrm{~m} \mathrm{Myr}^{-1}$ from similar nearby watersheds (Miller et al., 2013; Portenga et al., 2013) may be a good estimate for rates in Garner Run upstream of the knickpoint (Fig. 7). These rates are indeed 3-4 times lower than bedrock lowering rates inferred for the Shale Hills catchment (20-40 $\mathrm{m} \mathrm{Myr}^{-1}$; Ma et al., 2013; West et al., 2013, 2014), which lies downstream of the knickpoint on Shavers Creek.

The origin and genesis of these knickpoints are likely due to some combination of the following: regional base level adjustment on the Susquehanna River since the Neogene (3.5-15 Ma) due to epeirogenic uplift (Miller et al., 2013), 

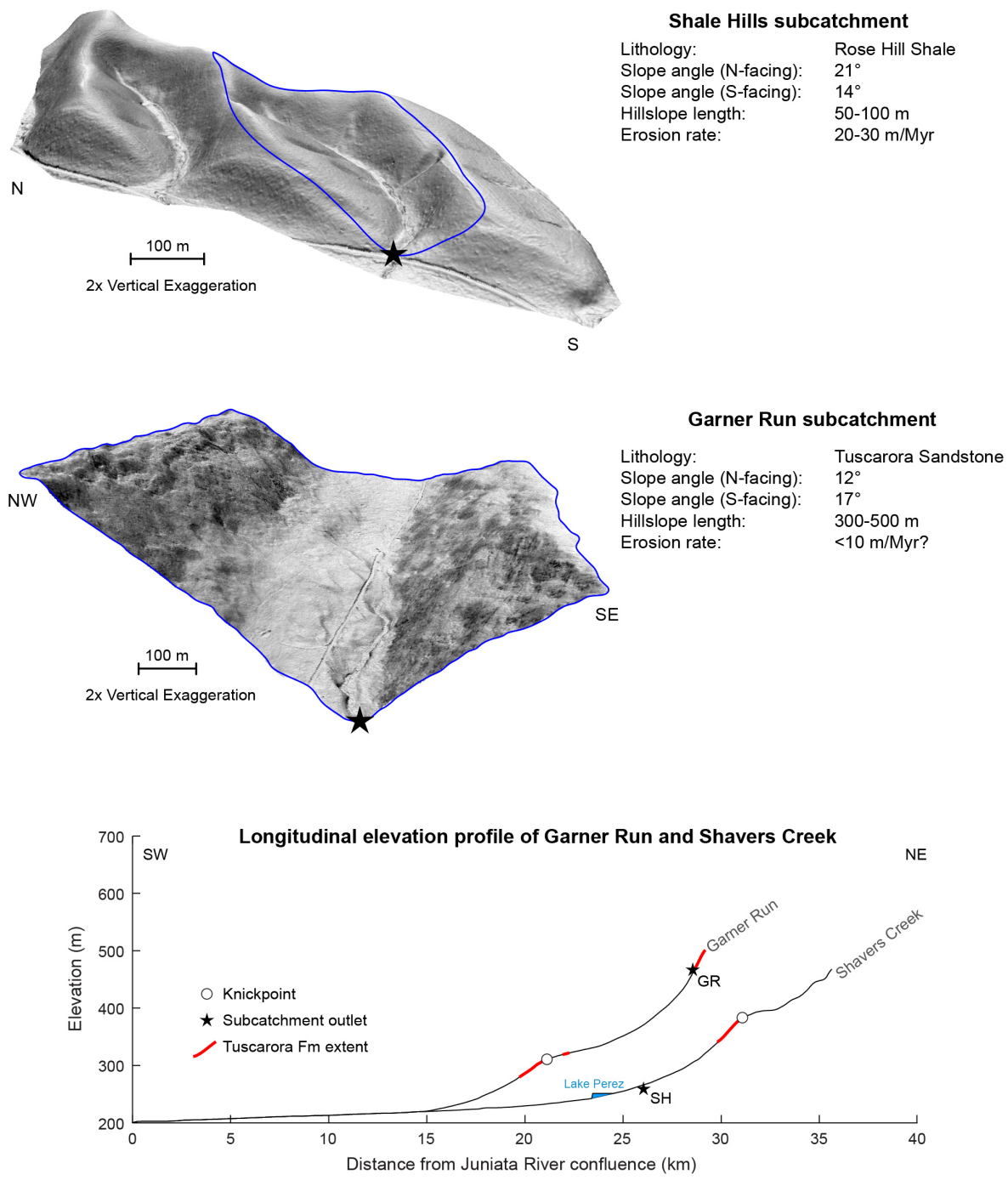

Figure 7. Perspective slopeshade maps (darker shades: steeper slopes) of Shale Hills (top panel) and Garner Run (middle panel) subcatchments, emphasizing differences in slope asymmetry and hillslope length. Soil production and erosion rates for Shale Hills subcatchment were measured based on U-series isotopes and meteoric ${ }^{10}$ Be concentrations in regolith, respectively (Ma et al., 2013; West et al., 2013, 2014). Erosion rate for Garner Run subcatchment is estimated based on detrital ${ }^{10} \mathrm{Be}$ concentrations from nearby sandstone catchments with similar relief (Miller et al., 2013). Bottom panel shows stream longitudinal profiles, highlighting the lithologic control on knickpoint locations. Note the location of the Shale Hills subcatchment $(\mathrm{SH})$ downstream of the knickpoint on Shavers Creek and the location of the Garner Run subcatchment (GR) upstream of the knickpoint on Garner Run.

stream capture and drainage reorganization (e.g., Willett et al., 2014), or temporal and spatial variations in bedrock exposure at the surface (e.g., Cook et al., 2009). Testing these competing controls will require additional direct measurements of bedrock lowering rates with cosmogenic nuclides at Garner Run, in addition to bedrock river incision models that can account for both variations in rock strength and temporal changes in relative base level.

In addition to variations in structure, lithology, and base level, Quaternary climate variations have left a strong imprint on the landscape of Garner Run and Shavers Creek in general. While the relict of the periglacial processes at Shale
Hills is mostly observed in the subsurface colluvial stratigraphy (West et al., 2013), at Garner Run these processes have left behind boulder fields, solifluction lobes, and landslides observed at the land surface (Fig. 6). Such features are found throughout central Pennsylvania south of the limit of the LGM (Gardner et al., 1991; Merritts et al., 2015). These features document a major reorganization of the uppermost CZ by processes such as frost cracking and permafrost thaw. For example, the Leading Ridge hillslope (the southern hillslope defining the Garner Run subcatchment, Fig. 5) is characterized by a hummocky topography on the 5-10 $\mathrm{m}$ scale, with abundant partially vegetated boulder fields. The other side of 
Table 2. Measurements and instrumentation for Tower HOG system.

\begin{tabular}{llll}
\hline Measurement & Manufacturer & Model & Collection frequency \\
\hline$\left[\mathrm{CO}_{2}\right],\left[\mathrm{H}_{2} \mathrm{O}\right]$ & LI-COR & LI-7500A $\mathrm{CO}_{2} / \mathrm{H}_{2} \mathrm{O}$ analyzer & $10 \mathrm{~Hz}^{\mathrm{c}}$ \\
3-D wind velocity, virtual temperature & Campbell Scientific & CSAT3 sonic anemometer & $10 \mathrm{~Hz}^{\mathrm{c}}$ \\
Precipitation & OTT Hydromet & Pluvio $^{2}$ weighing rain gauge & Every $10 \mathrm{~min}$ \\
$T_{\text {air }}$ & Vaisala & HMP60 humidity and temperature probe & Every $30 \mathrm{~min}$ \\
Relative humidity & Vaisala & HMP60 humidity and temperature probe & Every $30 \mathrm{~min}$ \\
Longwave radiation $^{\mathrm{a}}$ & Kipp \& Zonen & CGR3 pyrgeometer & Every $30 \mathrm{~min}$ \\
Shortwave radiation $^{\mathrm{a}}$ & Kipp \& Zonen & CMP3 pyranometer & Every 30 min \\
Snow depth $^{\mathrm{b}}$ & Campbell Scientific & SR50A sonic ranging sensor & Every 30 min \\
Digital Imagery & Campbell Scientific & CC5MPX digital camera & Every $24 \mathrm{~h}$ \\
\hline
\end{tabular}

a All four components of radiation (upwelling and downwelling (longwave and shortwave)) will only be measured at Shale Hills Tower HOG due to the location of the Garner Run Tower HOG. To model Garner Run we will use the Shale Hills data. ${ }^{b}$ Originally designed as part of tower system but will be deployed at Leading Ridge valley floor (LRVF) Ground HOG location because the Garner Run tower will be located outside of the catchment. ${ }^{\mathrm{c}}$ The turbulent fluxes (sensible and latent heat) and the momentum flux are computed at $30 \mathrm{~min}$ intervals via eddy covariance using these data collected at $10 \mathrm{~Hz}$.

the catchment - Tussey Mountain hillslope - is steeper at the top, has greater relief, retains evidence of past translational slides, and contains open, unvegetated boulder fields. At the foot of the Tussey Mountain hillslope is a strong slope break that demarcates a low-sloping region characterized by abundant solifluction lobes, which appear to have accumulated as a large, valley-filling deposit (Figs. 6, 7). Such features were either not as active or their evidence has been erased or buried at the Shale Hills subcatchment.

Many of these geomorphological features have controlled or been imprinted on $\mathrm{CZ}$ processes and human activities in Garner Run. For example, the modern flow pathways for surface and groundwater in Garner Run are significantly influenced by the forcing factors of tectonism, climate, and anthropogenic activity. Flow pathways are influenced (i) by topography inherited from geologic events from $10^{8}$ years before present, (ii) by variations in soil grain size as dictated by periglacial processes operating $10^{4}$ years ago, and (iii) by modern land use over the last $10^{2}-10^{3}$ years.

In terms of land use, the influence of anthropogenic activity in the catchment is relatively minor and consistent with the surrounding region. Neither Shale Hills nor Garner Run subcatchments show signs of having been plowed or farmed in row-crop agriculture, although some grazing may have occurred. The top of one of the ridges in Shale Hills appears to define a field edge. Both subcatchments were forested for at least 100 years. Based on historic aerial photographs, both watersheds contained intact, closed canopy forests in 1938 and show no sign of obvious stand level disturbance since that year. In the mid 1800 s, significant quantities of charcoal were made in this region to run several nearby iron furnaces. Given that charcoal hearths have been identified in the subcatchments from lidar, the subcatchments were probably cleared in the mid to late 1800 s as most available wood was used for charcoal making. This land use was also often associated with fires.
This short analysis of the geomorphology and land use highlights the influence of the forcing mechanisms (tectonism, climate, anthropogenic activity) that operate over a wide range of timescales and yet influence modern $\mathrm{CZ}$ processes. The CZO efforts document the importance of providing geologic and geomorphic context for investigation of the CZ.

\subsection{Water and energy flux measurements at Garner Run: Tower HOG}

Surface energy balance measurements (eddy covariance measurements of sensible and latent heat fluxes or upwelling terrestrial radiation or skin temperature) are needed to constrain Flux-PIHM (Shi et al., 2014b). Measurements of precipitation, atmospheric state, and incoming radiation are needed as inputs to the model. These measurements provide the data needed to simulate the catchment hydrology that is critical to understanding today's WEGSS fluxes. In addition, these fluxes are drivers for millennial-timescale landscape evolution (Fig. 1).

Instrumentation for measurements of water and energy flux measurements are designed as part of the "tower hydrological observation gear" - referred to here as Tower HOG (Tables 2 and S1). Precipitation will be measured near Garner Run on a road crossing Tussey Mountain that is also the site of a preexisting communications tower (see Fig. 3). A disdrometer (LPM, Theis Clima GmbH) and weighing rain gauge have been in use at Shale Hills since 2009 and 2006, respectively, to measure precipitation. To measure precipitation amount at Garner Run, we are installing a simpler instrument (Pluvio ${ }^{2}$, OTT Hydromet weighing rain gauge). Measurements will be compared to the National Atmospheric Deposition Program (NADP) measurements and samples of rainwater. According to the nearest NADP site, Garner Run receives $1006 \mathrm{~mm}_{\text {year }}{ }^{-1}$ precipitation with an average $\mathrm{pH}$ of 5.0 (Thomas et al., 2013).

Eddy covariance and radiation instrumentation (Table 2) will also be implemented on the preexisting communications 
tower on the Tussey Mountain ridgeline (Fig. 3). Although located outside of the subcatchment, the measurement footprint for the tower will be sensitive to fluxes from forests representative of those in Garner Run. The complex terrain at Shale Hills and Garner Run makes eddy covariance measurements difficult to interpret in stable micrometeorological conditions. Since the primary energy partitioning happens during the day when the atmosphere is typically unstable, daytime sensible and latent heat flux measurements are sufficient to constrain the hydrologic modeling system. Daytime carbon dioxide flux measurements will inform the biogeochemical modeling system.

\subsection{Vegetation mapping}

Vegetation impacts today's WEGSS fluxes and is known to have influenced regolith formation and sediment transport over geologic time. As we study subcatchments to understand budgets, we seek to learn enough about vegetation to extrapolate WEGSS fluxes to the Shavers Creek watershed. As described below, we once again use the geomorphological framework to design the measurement strategy for vegetation. We also want to understand the biogeochemical controls on fluxes of nutrients such as nitrate out of Shavers Creek. Ultimately, an OSSE will be run to compare measurements to model predictions as a way to determine the important parameters for predicting carbon and nitrogen fluxes. It may also be necessary to determine the effect of individual tree species on $\mathrm{N}$ flux (Williard et al., 2005).

As part of the geomorphological measurement strategy, we mapped the vegetation in Garner Run subcatchment across the Ground HOG catena (ridge top, midslope, and valley floor positions on one side of catchment and one midslope site on the other side; Fig. 5). The objective of the catenabased stratified sampling design was to measure spatial variability in vegetation, under the assumption that landscape position was an important control on vegetation. These measurements set the stage for planned remeasurements to understand temporal variability. For example, future assessments will quantify aboveground biomass, an important carbon pool. Variability in forest composition, standing biomass, and productivity across a watershed is generally related to gradients in biotic and abiotic resources such as soil chemistry or structure, water flux, and incoming solar energy. Therefore, the relatively restricted vegetation analysis design (Fig. 5) will be upscaled based on the team's developing knowledge of the distribution of soils across the watershed as well as lidar-based estimates of tree biomass and seasonal patterns of leaf area index and tree diameter growth. Given that we have not yet run an OSSE for C or N fluxes, our measurements of vegetation are relatively broad to enable such future analysis.

Vegetation measurements are important not only for $\mathrm{C}$ and $\mathrm{N}$ fluxes but also for water flux. At Shale Hills, seasonal variation in tree transpiration has been estimated using tree sap flux sensors (Meinzer et al., 2013). While we sampled many different tree species in multiple locations at Shale Hills (Fig. 2), a more restricted number will be sampled at Garner Run. For example, sap flux sensors are planned for only the midslope positions of Ground HOG (Fig. 5). While eddy flux and soil moisture dynamics provide estimates of total transpiration and evaporation, sap flux provides direct estimates of tree transpiration that can constrain model predictions of transpiration. Collectively, these measures will help evaluate Flux-PIHM model processes. In addition, all approaches to measuring water fluxes are imperfect; errors can best be constrained when multiple approaches are used.

In addition to these sap flux measurements limited to midslope pits, vegetation has been sampled in linear transects parallel to the slope contour at each of the four soil pits (Fig. 5; Sect. 3.4), i.e., at Leading Ridge ridge top (LRRT), Leading Ridge midslope (LRMS), Leading Ridge valley floor (LRVF), and Tussey Mountain midslope (TMMS). Each vegetation transect was $10 \mathrm{~m}$ along the direction perpendicular to the valley axis and $\sim 700-1400 \mathrm{~m}$ parallel to the valley axis.

Measurements along the transects yielded vegetation and forest floor cover data for 4.1 ha in the subcatchment (Table 3). The transects provide vegetation input data for land surface hydrologic models and also evaluation data for a spatially distributed biogeochemistry model (Flux-PIHMBGC; Table 1). In the transected area, 2241 trees $>10 \mathrm{~cm}$ diameter at breast height were measured, mapped, and permanently tagged. Understory vegetation composition was measured at $5 \mathrm{~m}$ intervals along transects, and coarse woody debris was measured in $25 \mathrm{~m}$ planar transects parallel to the main transect, spaced every $100 \mathrm{~m}$. Forest floor cover was classified as rock (typically boulder clasts from periglacial block fall), bare soil, or leaf litter every $1 \mathrm{~m}$ along each transect, and the dimensions ( $a, b, c$ axes) of the five largest exposed rocks were recorded every $25 \mathrm{~m}$. Forest floor biomass was measured every $25 \mathrm{~m}$ along transects by removing the organic horizon from a $0.03 \mathrm{~m}^{2}$ area for laboratory analysis: samples were dried, weighed, and measured for carbon loss on ignition.

The transect observations document variations in vegetation along the catena (Table 3), as well as spatial variation in vegetation at each position. For example, mean tree basal area (BA; the ratio of the total cross-sectional area of stems to land surface area) in the LRRT transect is $25.3 \mathrm{~m}^{2} \mathrm{ha}^{-1}$ with measurements ranging from 0 to $79 \mathrm{~m}^{2} \mathrm{ha}^{-1}$. The subcatchment contains a dry oak-heath community type (Fike, 1999), primarily consisting of chestnut oak (Q. montana), red maple (Acer rubrum), black birch (Betula lenta), black gum (Nyssa sylvatica), and white pine (Pinus strobus) in the overstory, with a thick heath understory of mountain laurel (Kalmia latifolia), blueberry (Vaccinium sp.) and huckleberry (Gaylussacia sp.) species, and rhododendron (Rhododendron maximum) along Garner Run.

The transect work also highlighted a type of measurement that we had not needed for Shale Hills but which our models 
Table 3. Vegetation sampling in the Garner Run subcatchment.

\begin{tabular}{|c|c|c|c|c|c|c|c|c|}
\hline Site* & $\begin{array}{r}\text { Sample } \\
\text { area } \\
\text { (ha) }\end{array}$ & $\begin{array}{r}\text { Tree basal } \\
\text { area } \\
\left(\mathrm{m}^{2} \mathrm{ha}^{-1}\right)\end{array}$ & $\begin{array}{l}\text { Tree density } \\
\text { (trees ha }^{-1} \text { ) }\end{array}$ & $\begin{array}{r}\text { Tree species } \\
\text { richness } \\
\text { (no species) }\end{array}$ & $\begin{array}{l}\text { Dominant tree species } \\
\text { (\% basal area) }\end{array}$ & $\begin{array}{r}\text { Forest floor } \\
\text { cover } \\
(\% \text { rock })\end{array}$ & $\begin{array}{r}\text { Mean rock } \\
\text { diameter } \\
(\mathrm{cm})\end{array}$ & $\begin{array}{r}\text { Organic } \\
\text { horizon C } \\
\left(\mathrm{g} \mathrm{m}^{-2}\right)\end{array}$ \\
\hline LRRT & 1 & 25.3 & 607 & 9 & $\begin{array}{l}\text { Quercus prinus }(44 \%) \\
\text { Acer rubrum }(19 \%) \\
\text { Pinus strobus }(19 \%) \\
\text { Nyssa sylvatica }(12 \%)\end{array}$ & 16 & 29 & 1775 \\
\hline LRMS & 1.4 & 25.1 & 610 & 12 & $\begin{array}{l}\text { Betula lenta }(37 \%) \\
\text { Quercus prinus }(21 \%) \\
\text { Nyssa sylvatica }(15 \%) \\
\text { Quercus rubra }(10 \%)\end{array}$ & 28 & 45 & 2208 \\
\hline LRVF & 0.7 & 24.6 & 371 & 14 & $\begin{array}{l}\text { Quercus rubra }(26 \%) \\
\text { Betula lenta }(23 \%) \\
\text { Quercus prinus }(20 \%) \\
\text { Acer rubrum }(14 \%)\end{array}$ & 36 & 43 & 1122 \\
\hline TMMS & 1 & 18.5 & 519 & 9 & $\begin{array}{l}\text { Acer rubrum }(32 \%) \\
\text { Betula lenta }(29 \%) \\
\text { Nyssa sylvatica }(25 \%)\end{array}$ & 34 & 60 & $\mathrm{n} / \mathrm{a}$ \\
\hline
\end{tabular}

* LRRT: Leading Ridge ridge top; LRMS: Leading Ridge midslope; LRVF: Leading Ridge valley floor; TMMS: Tussey Mountain midslope. Measurements were made in linear belt transects $700-1400 \mathrm{~m}$ long and $10 \mathrm{~m}$ wide centered at each soil pit position (Fig. 5).

and observations are showing is important in the new subcatchment: the fraction of land surface covered by boulders. At LRRT, $16 \%$ of points sampled every meter fell on rock. Furthermore, rock coverage at some transect points was as high as $100 \%$ or as low as $0 \%$. Vegetation and surface rockiness data from transects will be combined with a suite of ground and remotely sensed measurements from the watershed such as slope, curvature, aspect, solar radiation, and soil depth to model vegetation dynamics from environmental conditions and interpolate vegetation structure in areas of the watershed not directly sampled. Future remeasurements along transects will allow assessment of carbon uptake in vegetation, as well as changes in forest composition and structure.

Additional key vegetation parameters will be assessed at the soil pits described in Sect. 4.4 and Table S2. These additional measurements include root distributions, leaf area index (LAI; described in the next paragraph), litter fall, tree diameter growth, and tree sap flux. Root distributions are being measured at all four soil pits in Garner Run using soil cores to assess the high length densities near the surface. Root distributions, combined with soil water depletion patterns, can allow the estimation of the depth of tree water use over the season. Depth of tree water use, an input parameter in the PIHM suite of models, is currently derived from a lookup table (http://www.ral.ucar.edu/research/ land/technology/lsm/parameters/VEGPARM.TBL) to determine the rooting depth of each land cover type. We will explore whether the use of field-measured rooting depth as model input improves the modeling of water uptake. In addition, profile wall mapping is being used to analyze the ar- chitecture, mycorrhizal colonization, and anatomy of deep roots. By characterizing and understanding the controls on root traits along a hillslope, we will eventually be able to use such observations to inform models of both water cycling (Flux-PIHM) and regolith formation (RT-Flux-PIHM; see Table 1).

At weekly intervals in the spring and fall and monthly intervals during the summer, LAI will be assessed with a Li2200 plant canopy analyzer (LI-COR Inc., Lincoln, Nebraska USA). The Moderate Resolution Imaging Spectroradiometer (MODIS) also provides remotely sensed 8-day composite LAI (Knyazikhin et al., 1999; Myneni et al., 2002). The MODIS LAI product, however, has a spatial resolution of $1 \mathrm{~km}^{2}$, which cannot resolve the spatial structure in LAI within small watersheds. The product also has a notable bias compared to field measurements (e.g., Shi et al., 2013). The LAI field measurements will be used for detailed information on leaf phenology, which is an important driver for the modeling of water and carbon fluxes for land surface and hydrologic models (e.g., PIHM, Flux-PIHM; Table 1), and provides calibration or evaluation data for biogeochemistry models like Flux-PIHM-BGC (Naithani et al., 2013; Shi et al., 2013).

Another important value we must estimate is net primary productivity (NPP). With NPP it is possible to constrain carbon and nutrient fluxes in vegetation stocks, which can be large components of the overall budgets. To estimate aboveground NPP, we will measure annual variation in trunk growth with dendrobands emplaced on examples of each of the six dominant tree species near each soil pit site. In addition, traps at each soil pit will collect litter fall for assess- 
ment. One of the key model outputs of Flux-PIHM-BGC is NPP, which can be evaluated using these measured data.

\subsection{Soil pit measurements and Ground HOG instrumentation}

\subsubsection{Soil observations}

The uplands of the Garner Run subcatchment land surface falls into one of three categories: (i) fully soil mantled with few boulders emerging at the ground surface, (ii) bouldercovered with tree canopy, and (iii) boulder-covered without tree canopy. The coarse blocks of the Tuscarora sandstone range in diameter from $\sim 10$ to $200 \mathrm{~cm}$, making it challenging to excavate large soil pits (Table 3). To assess the spatial heterogeneity of soils in the Garner Run subcatchment, we therefore focused efforts on four soil pits: three on the northfacing planar slope of Leading Ridge (LRRT, LRMS, LRVF) and one midslope pit on the south-facing slope of Tussey Mountain (TMMS) (Fig. 5). Three pits were dug by hand until deepening was impossible (LRRT, LRMS, and TMMS). The LRVF pit was dug by hand and then deepened using a jackhammer until the inferred contact with intact bedrock was reached. The pits were excavated in the following soil series: TMMS, LRRT, and LRMS (Hazleton-Dekalb association, very steep), and LRVF (Andover extremely stony loam, $0-8 \%$ slopes). This deployment of observations in soil pits along a catena, with an additional pit on the opposite valley wall, is here referred to as Ground HOG (Fig. 5 and Figs. S1, S2 in the Supplement) and is the result of our focus on a minimalist sampling design.

This design was informed by observations at Shale Hills and the new subcatchment and by modeling conceptualizations. As discussed earlier, the Shale Hills subcatchment upland land surface falls into one of two categories: hillslopes or swales. In contrast, we observed little evidence for swales in Garner Run. All four pits in the new subcatchment were therefore located on roughly planar or somewhat convex-up hillslopes (see below). The rationale for the positions of the pits is as follows. First, regolith formation at a ridge top is the simplest to understand and model (see, for example, Lebedeva et al., 2007, 2010) because net flux of water is largely downward and net earth material flux is upward over geological time. We are now developing Regolith-RT-PIHM to simulate regolith development quantitatively for such 1-D systems, using constraints from cosmogenic isotope analysis (Table 1). The next level of complexity is a convex-upward but otherwise planar hillslope. The intent for Regolith-RTPIHM is that it will be able to model hillslopes as 2-D systems (e.g., Lebedeva and Brantley, 2013). Soil pits along a convex-upward but otherwise planar hillslope such as those described for Shale Hills (Jin et al., 2010) can be used to parameterize both 1-D and 2-D models of regolith formation. Third, while both planar hillslopes and swales are important at Shale Hills (Graham and Lin, 2010; Jin et al., 2011;
Thomas et al., 2013) the lack of swales at Garner Run allows focus on just one catena in the minimalist design. (In fact the lack of swales in the sandstone catchment is one of the observations that we hope we can eventually explain). Finally, the importance of aspect in soil development and WEGSS fluxes has been noted on shale at Shale Hills (Graham and Lin, 2010, 2011; Ma et al., 2011; West et al., 2014), as well as on sandstones in Pennsylvania (Carter and Ciolkosz, 1991). For that reason, Ground HOG includes one pit on the northern side of the catchment (Fig. 5).

We will use numerical models to explore regolith formation and to extrapolate to other hillslopes within Shavers Creek watershed. This highlights the importance of understanding the soil to the $\mathrm{CZ}$ effort. Soil provides a record of both transport of rock-derived material as well as fluxes of water over the period of pedogenesis. For example, the pits at Garner Run are characterized from the land surface downward by a thin organic layer, a rocky layer, a leached layer characterized by sand-sized grains with few large clasts, a sandy mineral soil with a thin layer of accumulated organic and sesquioxide material, and a deeper clay-rich layer with larger interspersed rock fragments (Fig. S3; Table S2). Depth intervals of the soil every $10 \mathrm{~cm}$ and from basal rocks show variations in chemistry (Tables S3, S4) and are being analyzed for grain size, organic matter, and mineralogy.

These soil observations yield further clues to the history of the landscape. The Garner Run subcatchment has been mapped to lie on Lower Silurian Tuscarora sandstone (Flueckinger, 1969). Interpreted as reworked beach sediments (Cotter, 1982), this sandstone has been metamorphosed to a highly indurated quartzite. Bulk compositions of five rocks collected from the bottom of the five Ground HOG pits were averaged to estimate composition of the protolith (Table S3). These samples contain $>96 \mathrm{wt} \% \mathrm{SiO}_{2}$, very similar to published Tuscarora compositions (Cotter, 1982). Minor titanium (Ti), generally present in sandstones in highly insoluble minerals, was present in the parent (Table S3) and at even higher concentration in soils (Table S4). This enrichment in soil could be due to several processes during weathering: for example, retention of Ti from the protolith, losses of elements other than $\mathrm{Ti}$, or addition of $\mathrm{Ti}$ to the soil. If $\mathrm{Ti}$ in the soil was derived from protolith, loss or gain of other elements in the sandstone can be calculated from the mass transfer coefficient, $\tau_{i j}$, where $i$ is Ti and $j$ is an element that was lost or gained (Anderson et al., 2002; Brimhall and Dietrich, 1987). Assuming the $\mathrm{Ti}$ in soil was derived from the protolith, $\tau_{T i, j}$ values equal 0 within error for $\mathrm{Al}, \mathrm{Mg}$, and $\mathrm{Fe}$, indicating that they were neither added nor depleted compared to Ti. In contrast, $\tau_{T i, K}>0$, consistent with addition of $\mathrm{K}$ to the soil (Fig. 8). Error bars on many of the elements are very large because of the variability in the low concentrations of all elements except $\mathrm{Si}$ and $\mathrm{O}$.

According to published arguments for this formation in this region, the thin and poorly developed ridgetop soil is likely residual (Ciolkosz et al., 1990). In contrast, soils 


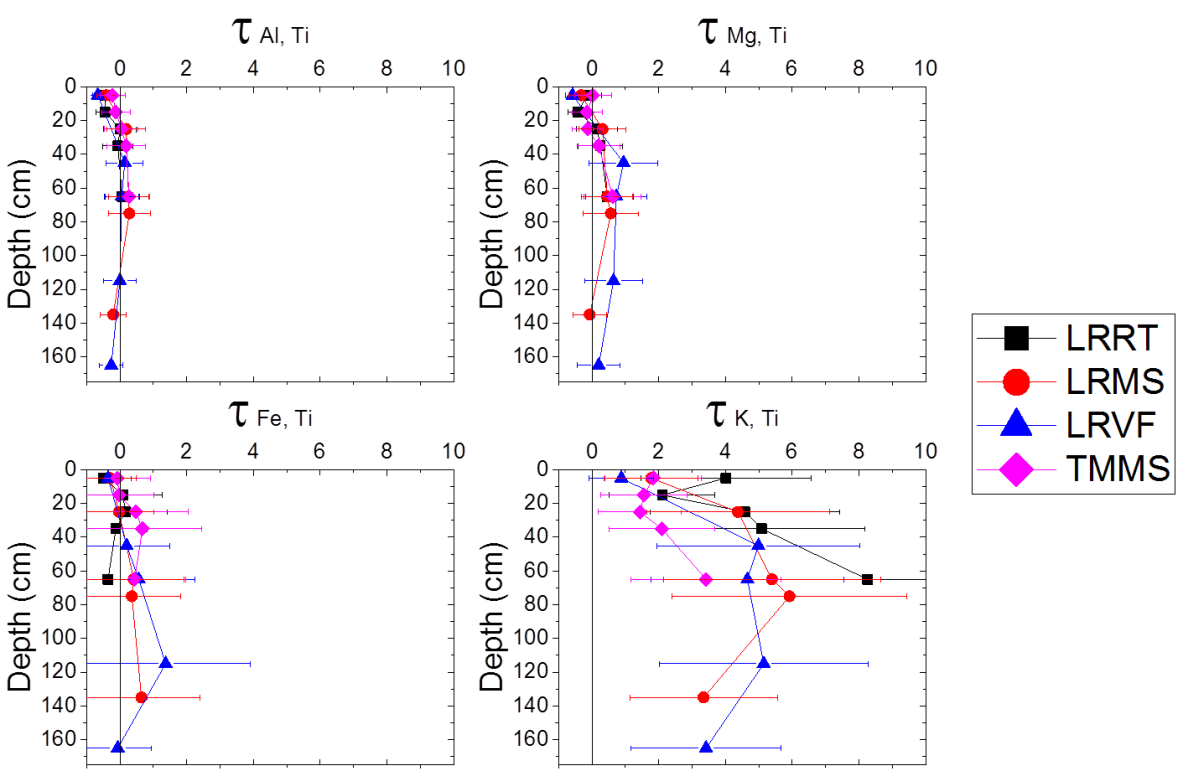

Figure 8. Plots of normalized concentration $(\tau)$ versus depth for soils analyzed from the four Garner Run subcatchment soil pits (LRVF, LRMS, LRRT, TMMS). $Y$ axis indicates the depth below the organic-mineral horizon interface. $\tau$ is the mass transfer coefficient determined using parent composition estimated as the average of five rocks (Table S3) from the bottom of several of the pits based on the assumption that Ti derives from protolith and is immobile. If parent is correctly estimated, $\tau=-1$ when an element is $100 \%$ depleted, $\tau=0$ when no loss or gain has occurred, and is $\tau>0$ when the element has been added to the profile compared to Ti in the parent material.

on hillslopes likely developed not only from rock in place but also from colluvium (Fig. 5). Furthermore, previous researchers have pointed out that soils in central Pennsylvania commonly show a brown-over-red layering that may indicate two generations of weathering, i.e., a previously weathered red layer which was then covered by a colluvial layer that experienced additional weathering (the brown layer) (Hoover and Ciolkosz, 1988). Although the soils here did not show a strong brown-over-red color signature (Fig. S3), clay-rich soil at depth may document soil formation before the LGM (Table S2). The addition of $\mathrm{K}$ to the soils, even in the residual soils at the ridgetop (Fig. S3), is another complexity. K could have been added as exogenous dust inputs which were very important during and immediately after glacial periods (Ciolkosz et al., 1990). Alternatively, K-containing clay particles could have percolated downward from weathering of the overlying units such as the Rose Hill shale before it was eroded away (Fig. 4). Such movement of fines downward from the Rose Hill have been observed at Shale Hills (Jin et al., 2010): such particles could have been added to the underlying Tuscarora and then retained in the soil. In that case, the assumed protolith composition could be erroneous, especially if Ti was added from the downward infiltrating fines. $\mathrm{K}$ enrichment could also be explained by shales within the Tuscarora formation itself (Flueckinger, 1969). If these interfingered shales were the protolith of the observed soils, this would mean that our estimated protolith composition was K-deficient. Thus, soil analysis (Fig. 8) leads to interesting hypotheses that will be investigated.

\subsubsection{Ground HOG}

The Ground HOG instrumentation enables the in situ measurement of soil moisture and temperature, as well as gas and pore-fluid compositions, all at multiple depths (Figs. 5, S2). Ground HOG complements the atmospheric measurements at Tower HOG (Sect. 3.2). Because Ground HOG sites are difficult to access, measurements were automated to the extent possible. However, the lack of access to electricity and the cost of automated sensors (for $\mathrm{CO}_{2}$ for example) meant that a completely automated monitoring system was unfeasible as well. Therefore, our final approach (Fig. S2) included a few automated components recording a continuous time series of data, coupled with additional components to be monitored manually but with lower temporal resolution.

In selecting depths for soil sampling we wanted to instrument the site so that results could be compared across all watersheds. Thus, we focused on a depth-based (as opposed to horizon-based) sampling scheme. In addition, we wanted to emphasize surface soils that have the highest water and biogeochemical flux rates. These layers also have the strongest influence on the atmospheric boundary layer. At the same time, we wanted to also document deep soil processes critical to understanding weathering and subsurface flow paths. Thus, our final depth distribution included samples at 10, 20, and $40 \mathrm{~cm}$ from the top of the mineral soil (we used the top of the mineral soil as the depth reference because the $\mathrm{O}$ horizon depth varies greatly across the sites and among land use types) and $20 \mathrm{~cm}$ above the bottom of the soil pit (coded "D- 
20"). At these four depths we installed one to four component devices of the Ground HOG in each pit.

Automated soil moisture and temperature sensors (Hydra Probe, Stevens Water Monitoring Systems, Inc. Portland, OR) were emplaced to monitor at 10,20 , and $40 \mathrm{~cm}$ depths on the uphill face of each pit (Fig. S2). In addition, timedomain reflectrometry (TDR) waveguides (Jackson et al., 2000) for manual point estimates of soil moisture were installed at the same depths plus D-20 on the uphill pit face and the left and right pit faces (facing uphill). Waveguides are paired metal rods on a single cable that conduct a signal for time-domain reflectometry. The rods are $20 \mathrm{~cm}$ long and handmade (Hoekstra and Delaney, 1974, Topp et al., 1980; Topp and Ferre, 2002). We placed 12 (four depths and three pit faces) in each pit. The automated sensors were emplaced at depths expected to have the most dynamic soil moisture. In contrast, the waveguides measure deep soil moisture where temporal variability is expected to be low. The use of waveguides added spatial replication at all depths (Figs. 5, S2).

Colocated with every soil moisture waveguide is an access tube to sample soil gas for measurements of the depth distribution of $\mathrm{CO}_{2}$ and $\mathrm{O}_{2}$ at a low temporal frequency. At $20 \mathrm{~cm}$ below the soil surface and $20 \mathrm{~cm}$ above the bottom of the uphill face of the pit, sensors are continuously measuring soil $\mathrm{CO}_{2}\left(\mathrm{GP} 001 \mathrm{CO}_{2}\right.$ probe, Forerunner Research, Canada) and $\mathrm{O}_{2}$ (SO-110 Sensor, Apogee Instruments, Utah, USA) at the two midslope catena positions. We selected the midslope catenas for these sensors because they provide the best locations for contrasting north and south aspects. We placed one sensor at the D-20 location to document controls on acid and oxidative weathering near the bedrock interface. The second sensor is near the surface to monitor a zone of high biological $\mathrm{CO}_{2}$ and $\mathrm{O}_{2}$ processing. We did not install the sensors at the shallowest depth $(10 \mathrm{~cm})$ because we found that high diffusion and advection at shallower depths causes the gas concentrations at $10 \mathrm{~cm}$ to reflect atmospheric conditions, providing less information on soil biology (Jin et al., 2014; Hasenmueller et al., 2015).

Lysimeters (Super Quartz, Prenart Equipment ApS, Denmark) have been emplaced to allow periodic manual sampling of soil pore water for chemical analysis at 20 and D$20 \mathrm{~cm}$ depths in all catena locations. The rationale for these depths is the same as described above for the automated $\mathrm{CO}_{2}$ and $\mathrm{O}_{2}$ sensors (they are colocated in the midslope pits). Overall, these Ground HOG measurements will parameterize the regolith formation models (Table 1) and will be used to test hypotheses linking hydrology, biotic production and consumption of soil gases, and weathering rates.

\subsection{Upscaling from the pits to the catena using geophysics}

To supplement the Ground HOG observations, we use geophysical and large-footprint methods to interpolate between and extrapolate beyond soil pits. For example, a cosmic-ray neutron detector (CR-1000B, Hydroinnova Inc.) has been emplaced to measure large-scale $(\sim 0.5 \mathrm{~km}$ radius) average soil moisture every $30 \mathrm{~min}$. This COSMOS unit, already used in a variety of ecosystems (Zreda et al., 2013), will measure spatially averaged (3-D) soil moisture content within the watershed. Data processing methods have been developed that accounts for various types of moisture storage (e.g., canopy storage, snow, water vapor; Franz et al., 2013; Zweck et al., 2013). The sensor has been installed near the LRVF pit to provide spatially averaged moisture estimates across the valley.

The COSMOS fills in the gap between small-scale point measurements (Fig. 5) and large-scale satellite remote sensing. The footprint of COSMOS is optimal for hydrometeorological model calibration and validation in small watersheds. One sensor was installed at Shale Hills in 2011, and we are currently testing the COSMOS data with PIHM. We anticipate that the results from both catchments will yield insights into the capabilities of cosmic-ray moisture sensing technology in steep terrain and will offer insights into the problem of upscaling soil moisture measurements.

Ground HOG measurements will be further complemented by geophysical mapping along the catenas, including ground-penetrating radar (GPR) transects of subsurface structure. Electromagnetic induction (EMI) mapping of soil electric conductivity will similarly be used to measure soil spatial variations between pits. We plan repeated GPR and EMI surveys, in combination with terrain analysis using lidar topography, to identify subsurface hydrological features and soil distribution using published procedures (Zhu et al., 2010a, b). We will also field-check regolith depths using augers, drills, etc. With repeated geophysical surveys over time (e.g., different seasons and/or before and after storm events), we can also explore temporal changes in heterogeneous soilscapes and subsurface hydrologic dynamics, as demonstrated at Shale Hills (Guo et al., 2014; Zhang et al., 2014).

Such geophysical mapping is necessary to link between and compare with soil pit point measurements. For example, depth to bedrock along the catenas will be mapped using the geophysical surveys and compared to pit measurements (Fig. 5). These data can be used for upscaling biogeochemical patterns and processes. For example, we expect that soil depth and soil moisture exert the strongest controls on variation in soil gas concentrations, as observed in many places, including Shale Hills (Hasenmueller et al., 2015; Jin et al., 2014). Empirical relationships among these variables developed at Ground HOG points can be coupled with catchment scale soil moisture (from COSMOS) and soil depth (from GPR) data to upscale soil gas characteristics to the whole catchment.

To exemplify the utility of this approach, results from an investigation completed using a ground-penetrating radar unit (TerraSIRch Subsurface Interface Radar System-3000) to map the depth to bedrock in the Garner Run hillslope near 

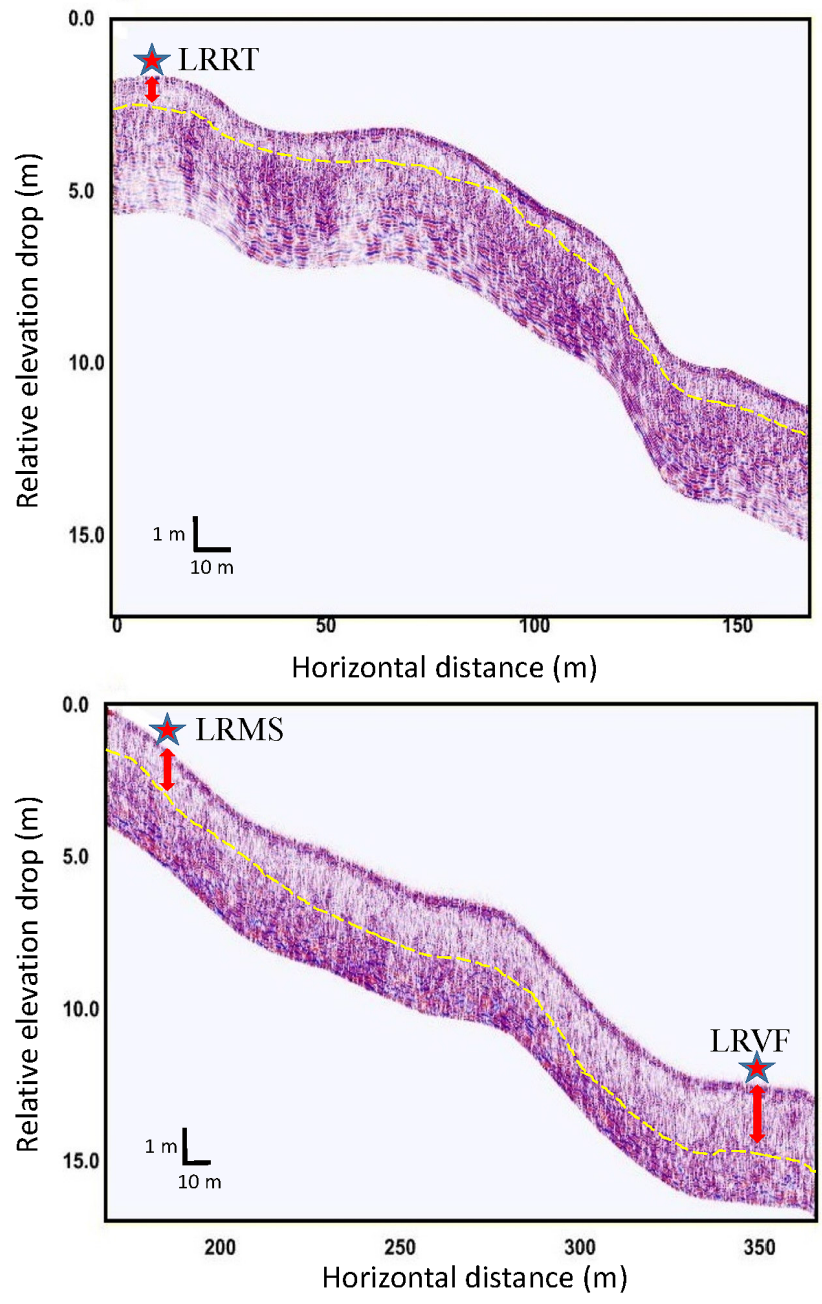

Figure 9. Ground-penetrating radar (GPR) transect of the Leading Ridge catena, showing inferred location of bedrock-soil interface (yellow dashed curve). The three soil pits (LRRT, LRMS, LRVF) are indicated by stars, with their observed depth to bedrock indicated by red arrow. LRRT and LRMS were dug by hand until refusal and LRVF was dug by hand and deepened with a jack hammer. GPR data are exaggerated 10 times in vertical dimension as compared to surface topography. Summary bedrock depths are tabulated in Table 4 .

the three major monitoring sites (LRVF, LRMS, LRRT) is shown in Fig. 9. Multiple GPR traverses were completed by pulling the antennae along the ground surface. A distancecalibrated survey wheel with encoder was bolted onto these antennae to provide greater control of signal pulse transmission and data collection. The survey wheel occasionally slipped in the challenging terrain, resulting in some errors. Relative elevation data were collected as described below along the traverse line to surface-normalize the data.

A traverse line from near Garner Run to the summit was established that ascends Leading Ridge in a nominally west to east direction from $\sim 494$ to $\sim 588$ ma.s.l. (Fig. 9). The
Table 4. Frequency distribution of bedrock depth measurements along GPR transect (Fig. 9).

\begin{tabular}{lrr}
\hline Depth to bedrock & Upper section & Lower section \\
\hline Shallow $(<0.5 \mathrm{~m})$ & 0.00 & 0.00 \\
Moderately deep $(0.5-1 \mathrm{~m})$ & 0.26 & 0.04 \\
Deep $(1-1.5 \mathrm{~m})$ & 0.51 & 0.48 \\
Very deep $(>1.5 \mathrm{~m})$ & 0.24 & 0.48 \\
\hline
\end{tabular}

dominant soils mapped along this traverse line (Table S2) include Andover, Albrights, Hazleton, and Dekalb. The very deep, poorly drained Andover and moderately well to somewhat poorly drained Albrights soils have been reported in general to have formed in colluvium derived from acid sandstone and shale on upland toe-slope and foot-slope positions. The moderately deep, excessively drained Dekalb and the deep and very deep, well-drained Hazleton soils formed on higher-lying slope positions in residuum weathered from acid sandstone. These soils have moderate potential for penetration with GPR.

The traverse line was cleared of debris but the ground surface remained highly irregular with numerous rock fragments and exposed tree roots that often halted the movement and caused poor coupling of the antennae with the ground. Flags were inserted in the ground at noticeable breaks in the topography along the traverse line. User marks were inserted on the radar records as the antenna passed these survey flags. Later, the elevations of these points were determined using an engineering level and stadia rod. The elevation data were entered into the radar data files and used to surface-normalize or terrain-correct the radar records.

In this preliminary investigation, the soil-bedrock interface was not easy to identify. This was attributed to poor antenna coupling with the ground surface in the challenging rocky terrain, noise in the radar records caused by rock fragments in the overlying soil, irregular and fractured bedrock surfaces, and varying degrees of hardness in both rock fragments and the underlying bedrock. These factors weakened the amplitude, consistency, and continuity of reflections from the soil-bedrock interface. Nevertheless, preliminary results are described below.

Figure 9 shows two surface-normalized plots of data collected with the $400 \mathrm{MHz}$ antenna as it was pulled from the summit of Leading Ridge to near Garner Run. Distance is measured from the summit area to near Garner Run. Differences in gross reflection patterns can be used to differentiate rock from soil, but the soil-bedrock interface is diffuse. We collected four repeated GPR transects using both 400 and $270 \mathrm{MHz}$ antenna. Compared with the $400 \mathrm{MHz}$ antenna, the lower resolution of the $270 \mathrm{MHz}$ antenna smoothed out irregularities in the bedrock surface and reduced the noise from smaller, less extensive subsurface features, thus improving the interpretability of the soil-bedrock interface. Based on a 
total of 14748 soil depth measurements from $\sim 400 \mathrm{~m}$ long GPR images along this traverse line, the interpreted depth to bedrock ranged from 0.58 to $2.42 \mathrm{~m}$ and averaged $1.37 \mathrm{~m}$ (Table 4; Fig. 9). Each entry in Table 4 indicates the frequency of depth to bedrock data collected with the $400 \mathrm{MHz}$ antenna along a traverse line, grouped into four soil depth classes. The GPR-derived soil depths are reasonable compared to the values we estimated in the soil pits (Fig. 9; Table S2).

\subsection{Hydrology: groundwater measurements}

Several methods are needed to characterize physical and chemical interactions of water with regolith and rock in a catchment. First, physical inputs and outputs to a catchment, including precipitation, interception, ET, soil infiltration, and groundwater discharge, must be understood. Often, groundwater flows are omitted from comprehensive hydrologymeteorology-vegetation models such as the Variable Infiltration Capacity (VIC) hydrologic model, or the Noah land surface model (LSM). However, at Shale Hills, we have estimated that roughly $50 \%$ of incoming water is evapotranspired and $5 \%$ reaches the regional groundwater table and returns to the stream as baseflow (Sullivan et al., 2016). At Garner Run, we also expect groundwater to play a significant role in streamflow and geochemical dynamics. For example, some researchers have found that drainage and runoff on sandstone catchments are controlled to a great extent by bedrock (Hattanji and Onda, 2004) and specifically by flow through fractures in the upper meters of sandstone beneath the soil (Williams et al., 2010). In this section and the next section we focus on quantifying fluid flow and transport of solutes into surface water and groundwater. We aim to measure the relative magnitudes, timing, and spatial variability of these fluxes. We emphasize methodologies for measuring and characterizing groundwater and stream water to identify subsurface flow paths of groundwater and the drivers and controls on water-rock interactions.

In the spirit of measuring only what is needed, well installation and solid-earth sampling by coring will be reduced compared to Shale Hills. At Shale Hills, 28 wells were emplaced and then intermittently monitored (Fig. 2). In Garner Run, deep samples (> $8 \mathrm{~m}$ ) have been extracted between Garner Run and Roaring Run from the Harry's Valley 1 well (HV1) drilled within the Garner Run catchment (see Fig. 3). Using a handheld drill, three shallow wells will be installed and cores will be collected at the catena sites (Fig. 5) and additional monitoring wells will be installed along hillslopes and the valley floor. From these wells, we will also sample solid-phase chemistry and mineralogy.

All core samples will be analyzed for bulk chemistry and mineralogy to characterize the weathering reactions and protolith. Where possible, we will install groundwater monitoring wells in boreholes, with screened intervals spanning the water table. Monitoring at the wells will include hourly water level measurements using autonomous pressure log- gers, hourly temperature measurements at two depths below the water table, and monthly water samples collected and analyzed for major ion chemistry. A pumping test will be conducted at the adjacent valley floor wells to measure aquifer storativity and hydraulic conductivity. Relative residence time of groundwater will be assessed from pathway analysis. If resources permit, $\mathrm{SF}_{6}$ and chlorofluorocarbons (CFCs) will be measured in groundwater samples to assess residence time in the subsurface, as we have done for Shale Hills (Sullivan et al., 2016).

Deep core samples and groundwater monitoring will provide a baseline understanding of the geologic and hydrologic system on the new sandstone lithology. Subsequent hypotheses about controls on weathering and hydrologic dynamics, as well as historical flow and solute fluxes, will be constrained by these observations at the catchment boundaries.

\subsection{Hydrology: stream water flow and chemistry measurements}

The Garner Run study reach is approximately $500 \mathrm{~m}$ long (Fig. 5) and consists of a rocky, often braided channel. We have installed a flume at the downstream end of the reach to measure discharge. Stage is continuously monitored using a pressure transducer (Hobo U-20, Onset Computer Corp., Hyannis, MA). Surface-water-groundwater (SW-GW) exchange characteristics have been measured using a shortterm deployment of a fiber-optic-distributed temperature sensor (FO-DTS) and two tracer injection tests. Stream chemistry, including dissolved oxygen (DO), $\mathrm{pH}$, total dissolved solids (TDS), $\mathrm{NO}_{3}^{-}, \mathrm{SO}_{4}^{2-}, \mathrm{Ca}, \mathrm{K}, \mathrm{Mg}, \mathrm{Mn}, \mathrm{Na}, \mathrm{Fe}$, and $\mathrm{Si}$, are measured biweekly or monthly in the field with handheld electrodes along the $500 \mathrm{~m}$ reach or by grab sampling and laboratory analysis (inductively coupled plasmaatomic emission spectroscopy, organic carbon analyzer, and ion chromatography).

Stream chemistry is also explored at the higher temporal resolution by using an s::can spectrometer and an autosampler during storm events (s::can GmbH, Vienna, Austria). The s::can is an in situ instrument capable of measuring such water quality parameters as $\mathrm{pH}$, TDS, dissolved organic carbon (DOC), $\mathrm{NO}_{3}^{-}, \mathrm{DO}, \mathrm{NH}_{4}^{+}, \mathrm{K}^{+}$, and $\mathrm{F}^{-}$. The chemistry and tracer test data will help quantify the flux of fluid and solutes through the subcatchment. The stream chemistry and discharge data will be combined with soil moisture, soil pore water chemistry, and groundwater data to estimate relative contributions to the stream, and underlying processes related to weathering in the near surface and aquifer.

Preliminary results from Garner Run indicate lower concentrations of $\mathrm{Ca}, \mathrm{Mg}$, and $\mathrm{K}$ compared to the stream discharging from Shale Hills. In addition, as expected, an initial constant injection tracer test at Garner Run revealed significant exchange with the subsurface during low-flow conditions $\left(\sim 0.004 \mathrm{~m}^{3} \mathrm{~s}^{-1}\right)$. Tracer test and temperature results suggest that the stream is losing water along some sections 

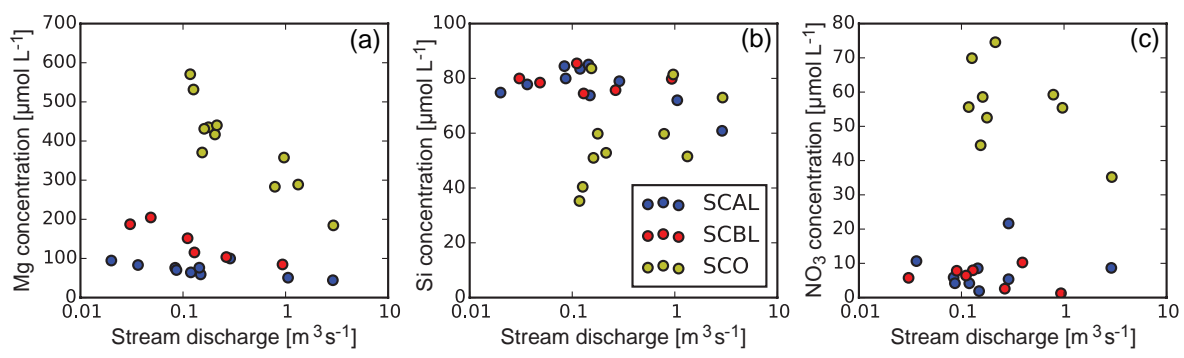

Figure 10. $\mathrm{Mg}(\mathbf{a}), \mathrm{Si}(\mathbf{b})$, and nitrate dissolved concentrations (c) (filtered at $0.45 \mu \mathrm{m}$ ) and stream discharge measured at three locations on Shavers Creek: above the lake (SCAL, blue), below the lake (SCBL, red), and at the outlet (SCO, yellow) as shown in Fig. 3.

of the $500 \mathrm{~m}$ experimental reach and gaining water in others. Both the FO-DTS and stream chemistry data indicate significant input of spring water at $\sim 100 \mathrm{~m}$ downstream of the Ground HOG catena (Fig. 5), which is chemically distinct from the upstream surface water and local groundwater sampled from the deep HV1 well. The distributed temperature sensing (DTS) system time series data will be analyzed to identify locations and magnitudes of inputs to the stream, as well as characteristic responses to rainfall events. In combination with the tracer tests, DTS, and chemistry results, we will use well logs and lidar topography to explain the lithological and geomorphologic controls on the SW-GW system.

To characterize the major controls and processes governing WEGSS fluxes through the entire Shavers Creek catchment, we are making strategic measurements across the watershed to represent variability: stream discharge, stream chemistry, lithology, and geomorphology. Specifically, stream discharge and chemistry are being monitored along the main stem of Shavers Creek (SCAL - Shavers Creek above lake; SCBL - Shavers Creek below lake; and SCO - Shavers Creek outlet; Fig. 3). At each location we are monitoring stage continuously using pressure transducers (Hobo U-20, Onset Computer Corp., Hyannis, MA) and using periodic discharge measurements to construct stagedischarge rating curves. SW-GW exchange characteristics will be measured as the channel crosses varying lithologies using a series of tracer injection tests. Analyses of stream chemistry from the main stem of Shavers Creek provide a spatial integration of solute behavior from upstream lithologies and land use types. Eventually, with data from the three subcatchments on shale, sandstone, and calcareous shale (Fig. 3), we will make estimates for non-monitored catchments and test upscaled estimates of the processes observed in each small watershed.

Preliminary stream chemistry and discharge results indicate significant variability among the three monitoring locations along Shavers Creek (Fig. 10). We see declining concentrations with increasing discharge for $\mathrm{Mg}$ and $\mathrm{Ca}$ (not shown) and somewhat chemostatic behavior for $\mathrm{Si}, \mathrm{K}$, nitrate, and others. In this context, chemostatic is used to refer to concentrations of a stream that vary little with discharge
(Godsey et al., 2009). Concentrations of Si decrease downstream (a dilution trend), while concentrations increase for $\mathrm{Mg}$ and nitrate, presumably due to agricultural amendments in the lower half of Shavers Creek watershed where land use includes farmland. The variety of behaviors will be investigated with respect to land use and lithology changes through the catchment.

\section{Model-data feedbacks}

Throughout this paper we have described the two-way exchange of field-model insights needed to maximize the efficiency of $\mathrm{CZ}$ science. To understand the $\mathrm{CZ}$ requires models on all temporal and spatial scales. A measurement in most cases can be recorded as a number: the understanding that derives from that number requires a model. To the extent that models can be used to infer predictions about landscape behavior, field observations and measurements are necessary to provide data for calibration and testing.

The CZ approach of using models to cross from short to long timescales has an important major benefit. Investigations that target long timescales can tease out the effects of feedbacks and thresholds in complex systems that are difficult to discern in short-timescale studies. We thus use quantitative models to explore a vast range on both spatial and temporal scales. In this paper we emphasized our approach toward designing a CZO as a tool to understand the $\mathrm{CZ}$ as one integral system. We therefore emphasized only one modeling tool, the PIHM family of models. This cascade of models provides a quantitative way for different disciplines to interact regarding the $\mathrm{CZ}$ through the use of a shared suite of models. Our current conceptual understanding and our current computers do not allow us to produce one model that simulates the $\mathrm{CZ}$ on all timescales, hence the cascade of models (Table 1).

Such a suite of models is integral not simply for predicting landscape and ecosystem response but also to building a heuristic understanding of individual $\mathrm{CZ}$ processes that may not be apparent from first-order observations. System-level models are especially needed for proposing and testing hypotheses about feedbacks between climate, biota, and earth 
surface and near-surface processes. Although not emphasized here, we have also cited publications throughout this paper that describe the many smaller scales or disciplinaryspecific hypotheses and models that have been invoked to learn about individual $\mathrm{CZ}$ systems. For example, we point to our earlier observation of K enrichment in Garner Run soils (Fig. 8). We suggested several processes that could interact to explain data in Fig. 8, including preferential retention of some elements in protolith compared to others, depth variations in protolith composition, accumulation of fines from weathering formations above the current protolith, and dust additions. While first-order mass balance model calculations such as those implicit in Fig. 8 can be used to propose or test such hypotheses, the use of Regolith-RT-PIHM (Table 1) or WITCH (Godderis et al., 2006) to model regolith formation is necessary to quantitatively test the feasibility of such ideas. Better understanding of regolith formation will in turn inform the permeability distributions needed for hydrologic flow models in the CZO.

\section{Conclusions: measuring and modeling the $\mathrm{CZ}$}

Many environmental scientists worldwide are embracing the concept of the critical zone - the surface environment considered over all relevant timescales from the top of the vegetation canopy to the bottom of groundwater. $\mathrm{CZ}$ science is built upon the hypothesis that an investigation of the entire object - the CZ - will yield insights that more disciplinary-specific investigations cannot. To understand the evolution and dynamics of the $\mathrm{CZ}$, we are developing a suite of simulation models as shown in Table 1 (Duffy et al., 2014). These models are being parameterized based on measurements made at the SSHCZO which is currently expanding from less than 1 to $165 \mathrm{~km}^{2}$.

In this paper we described an approach for assessing the $\mathrm{CZ}$ in the larger watershed. In effect, our measurement design is a hypothesis in answer to the following question: if we want to understand the dynamics and evolution of the entire CZ, what measurements are needed and where should they be made? Our approach emphasizes upscaling from 1-D to 2-D to 3-D using a catena paradigm for ground measurements that is extended with geological, geophysical, lidar, stream, and meteorological measurements. Our data set has very little sampling replication within each catchment, and we have only designed for one catchment per parent material. This results from the tension between monitoring a core data set over time (a geological or hydrological approach) versus the replication that is needed for spatial characterization (a soil science or ecological approach). Our spatial design was chosen based on the implicit assumption that implementation of ground- and tower-based measurements (Ground HOG, Tower HOG) in each subcatchment could be upscaled to the entire watershed by interpolation and extrapolation, as well as modeling (Table 1). For example, we are testing the hy- pothesis that fewer soil pits are needed because we are using a regolith formation model and geological knowledge to site the few pits that we dig. If we find that our limited digging of soil pits is not successful in characterizing the regolith adequately - if our models of regolith formation do not match observations or our models of water flow through regolith do not simulate observations - more pits can be dug or new approaches toward geophysical measurements can be refined. As we build understanding, regolith formation models will be used to extrapolate point measurements of soil thickness and porosity from catena observations to the broader Garner Run subcatchment and to other similar subcatchments in the Shavers Creek watershed. In other words, the numerical models in Table 1 will be used to extend our interpretations beyond the limited observations.

The sampling design described here is also being augmented with brief measurement campaigns outside the subcatchments and outside Shavers Creek watershed as warranted. For example, while we will only monitor soil $\mathrm{CO}_{2}$ continuously at a few catena positions and soil depths, we augment these high-frequency data with spatially extensive but temporally limited measurements using manual soil gas samplers. Likewise, we are characterizing vegetation and surface soil properties at two to five additional catchments of each parent material type using the transect design initiated at Garner Run (Fig. 5). In general, these outside measurements will be discipline-specific excursions to understand a specific variable. This is a good example of targeted investigations that are not directly related to parameterization of the models in Table 1 for our CZO itself but are rather aimed at improving the process-based understanding that underlies models of $\mathrm{CZ}$ evolution. Another example is a set of measurements that are ongoing to investigate regolith formation and hillslope form in other catchments north of Shavers Creek where the erosion rates differ. Such targeted investigations can also be compared to output from sensitivity tests where pertinent models are used to explore the effect of the targeted variables (Table 1). Measurements outside the CZO may therefore highlight problems in our limited sampling scheme or modeling approaches that must be improved.

As we improve our understanding of the behavior of components of the CZ, the point is to discover system-wide patterns and processes. Throughout, upscaling will remain a challenge. There is no comprehensive mathematical model of the critical zone, partly because it would be arduous to parameterize and perhaps more importantly because we do not yet understand all the interacting governing processes (Fig. 1). The research in Shavers Creek, and the work done at other CZOs around the world, is an attempt to develop a system-wide process model (or ensemble of models) and to identify the essential measurements required for parameterization. Of great interest are robust conceptual models that aid in understanding the $\mathrm{CZ}$, but such conceptual understanding must also be encoded within complex numerical simulations that allow quantitative predictions for testing. Nonetheless, 
both conceptual and numerical models still include only a portion of the CZ. To really understand WEGSS fluxes quantitatively requires a model that successfully explains the dynamics between topography, groundwater levels, biota, atmospheric conditions, and regolith thickness; at present, we are working mostly with conceptual relationships drawn between pairs of factors (Fig. 1).

In our efforts, new observations are tested against and incorporated into the PIHM models to explore the evolution of the $\mathrm{CZ}$ over time. In this endeavor, we can also ask what success looks like. At a CZO, the point of data collection is to understand the $\mathrm{CZ}$ both on the scale of interest of the individual investigator and on the full spatial and temporal scale needed to project (earthcast) the CZ. Ultimately, success means that we gain deeper understanding of the system and can predict behavior in other places or with other data sets (e.g., tracers, water isotopes). Such testing is built in to our nested watershed approach (Fig. 3) and is also implicit in the design of the greater CZO network.

We can also imagine other indicators of success. For example, successful data sets will attract other researchers using other models. This in turn can lead to model-model intercomparisons. If other models provide better simulations of the catchment, this will drive development of better models. One example of a model-model intercomparison (RT-FluxPIHM versus WITCH-Flux-PIHM; Table 1) has already led to new insights.

Another indicator of success is adoption by others of the strategies developed to study the CZ. Such strategies include design of a sampling paradigm for an individual CZO, design of a larger network of CZOs, development of suites of models, or approaches for data assimilation. While the CZO enterprise is still young, publications in the literature already attest to growth in the use of the PIHM suite of models in other places (Kumar et al., 2013; Wang et al., 2013; Yu et al., 2015; Jepsen et al., 2015, 2016a, b) and growth in the use of the CZO concept worldwide (Banwart et al., 2012).

\section{The Supplement related to this article is available online at doi:10.5194/esurf-4-211-2016-supplement.}

Author contributions. S. L. Brantley, H. Lin, K. J. Davis, A. L. Neal, J. Kaye, and D. Eissenstat designed the study and wrote the sections on soil analysis, GPR, eddy correlation, GIS analysis, biogeochemical analysis, and tree root analysis, respectively. R. DiBiase spearheaded the geomorphological treatment, and T. Russo and B. Hoagland led the ground- and stream water research. Y. Shi performed the OSSE and worked on coupling models with PIHM. M. Kaye designed and led the vegetation surveys. L. Hill and J. Kaye designed and implemented the soil pit sensor research. A. Dere completed the soil descriptions. K. Brubaker contributed forest and land use descriptions. D. K. Arthur supervised overall data contributions.
Acknowledgements. Field help was provided by B. Forsythe, D. Pederson, and R. Davis. D. Arthur and J. Williams are acknowledged for data organization and A. Orr for photographing the soil pits. C. Duffy is acknowledged for leadership at Shale Hills and for PIHM. S. Macdonald is acknowledged for Garner Run soil geochemistry analysis. L. Li is acknowledged for implementation of the COSMOS at Garner Run and E. Kirby and P. Bierman for planning the cosmogenic measurements. J. Doolittle from the USDA-NRCS is acknowledged for help with GPR data collection. This work was funded by NSF Critical Zone Observatory program grants to C. Duffy (EAR 07-25019) and S. L. Brantley (EAR 12-39285, EAR 13-31726). Logistical support and data were provided by the NSF-supported Shale Hills Susquehanna Critical Zone Observatory. This research was conducted in Penn State's Stone Valley Forest, which is supported and managed by the Penn State's Forestland Management Office in the College of Agricultural Sciences. The Penn State Earth and Environmental Systems Institute and College of Agricultural Sciences are acknowledged for staff and funding support.

Edited by: N. Hovius

\section{References}

Amundson, R.: Soil formation, in: Treatise in Geochemistry: Surface and Ground Water, Weathering, and Soils, edited by: Drever, J. I., Elsevier Pergamon, Amsterdam, 1-35, 2004.

Anderson, S. P., Dietrich, W. E., and Brimhall, G. H.: Weathering profiles, mass balance analysis, and rates of solute loss: linkages between weathering and erosion in a small, steep catchment, Geol. Soc. Am. Bull., 114, 1143-1158, 2002.

Banwart, S., Menon, M., Bernasconi, S. M., Bloem, J., Blum, W. E. H., de Souza, D. M., Davidsdotir, B., Duffy, C., Lair, G. J., Kram, P., Lamacova, A., Lundin, L., Nikolaidis, N. P., Novak, M., Panagos, P., Ragnarsdottir, K. V., Reynolds, B., Robinson, D., Rousseva, S., de Ruiter, P., van Gaans, P., Weng, L., White, T., and Zhang, B.: Soil processes and functions across an international network of Critical Zone Observatories: Introduction to experimental methods and initial results, C. R. Geosci., 344, 758-772, 2012.

Bao, C., Li, L., Shi, Y., Sullivan, P. L., Duffy, C. J., and Brantley, S. L.: RT-Flux-PIHM: a hydrogeochemical model at the watershed scale, Water Resour. Res., submitted, 2016.

Berg, T. M., Edmunds, W. E., Geyer, A. R., and others: Geologic map of Pennsylvania, 2nd edn., Pennsylvania Geological Survey, 4th ser., Map 1, 3 sheets, scale $1: 250,000,1980$.

Beven, K. J.: Rainfall-Runoff Modelling: The Primer, WileyBlackwell, 2011.

Brantley, S. L. and Lebedeva, M.: Learning to read the chemistry of regolith to understand the Critical Zone, Annu. Rev. Earth Pl. Sc., 39, 387-416, 2011.

Brimhall, G. and Dietrich, W. E.: Constitutive mass balance relations between chemical composition, volume, density, porosity, and strain in metasomatic hydrochemical systems: results on weathering and pedogenisis, Geochim. Cosmochim. Ac., 51, 567-587, 1987.

Carter, B. and Ciolkosz, E.: Slope gradient and aspect effects on soils developed form sandstone in Pennsylvania, Geoderma, 49, 199-213, 1991. 
Chadwick, O. A. and Chorover, J.: The chemistry of pedogenic thresholds, Geoderma, 100, 321-353, 2001.

Ciolkosz, E. J., Carter, B., Hoover, M. T., Cronce, R., Waltman, W., and Dobos, R.: Genesis of soils and landscapes in the Ridge and Valley province of central Pennsylvania, Geomorphology, 3, 245-261, 1990.

Cook, K. L., Whipple, K. X., Heimsath, A. M., and Hanks, T. C.: Rapid incision of the Colorado River in Glen Canyon - insights from channel profiles, local incision rates, and modeling of lithologic controls, Earth Surf. Proc. Land., 34, 994-1010, 2009.

Cotter, E.: Tuscarora formation of Pennsylvania : guidebook, Society of Economic Paleontologists and Mineralogists, Eastern Section, 1982 field trip, Lewisburg, Pa., Dept. of Geology and Geophysics, Bucknell University, 1982.

Crutzen, P. J.: Geology of mankind, Nature, 415, 23-23, 2002.

Dietrich, W. E., Bellugi, D. G., Sklar, L. S., Stock, J. D., Heimsath, A. M., and Roering, J. J.: Geomorphic Transport Laws for Predicting Landscape Form and Dynamics, Dynamics, In Prediction, in: Geomorphology, Geophyscial Monograph, edited by: Wilcock, P. R., Iverson, R. M., 135, American Geophysical Union, 103-132, doi:10.1029/135GM09, 2003.

Duffy, C., Shi, Y., Davis, K., Slingerland, R., Li, L., Sullivan, P. L., Godderis, Y., and Brantley, S. L.: Designing a suite of models to explore critical zone function, Procedia Earth and Planetary Science, 10, 7-15, doi:10.1016/j.proeps.2014.08.003, 2014.

Duvall, A., Kirby, E., and Burbank, D.: Tectonic and lithologic controls on bedrock channel profiles and processes in coastal California. J. Geophys. Res.-Earth, 109, F03002, doi:10.1029/2003JF000086, 2004.

Ewing, S. A., Sutter, B., Owen, J., Nishiizumi, K., Sharp, W., Cliff, S. S., Perry, K., Dietrich, W., McKay, C. P., and Amundson, R.: A threshold in soil formation at Earth's arid-hyperarid transition, Geochim. Cosmochim. Ac., 70, 5293-5322, 2006.

Fike, J.: Terrestrial and palustrine plant communities of Pennsylvania, Bureau of Forestry, PA, Department of Conservation and Natural Resources, Pennsylvania, USA, 1999.

Flueckinger, L. A.: Report 176, Geology of a portion of the Allensville Quadrangle, Centre and Huntingdon Counties, Pennsylvania, Bureau of Topographic and Geologic Survey, Commonwealth of Pennsylvania State Planning Board, 1969.

Franz, T. E., Zreda, M., Rosolem, R., and Ferre, T. P. A.: A universal calibration function for determination of soil moisture with cosmic-ray neutrons, Hydrol. Earth Syst. Sci., 17, 453-460, doi:10.5194/hess-17-453-2013, 2013.

Gardner, T. W., Ritter, J. B., Shuman, C. A., Bell, J. C., Sasowsky, K. C., and Pinter, N.: A periglacial stratified slope deposit in the valley and ridge province of central Pennsylvania, USA: Sedimentology, stratigraphy, and geomorphic evolution, Permafrost Periglac., 2, 141-162, 1991.

Godderis, Y. and Brantley, S. L.: Earthcasting the future Critical Zone, Elementa, 1, 1-10, doi:10.12952/journal.elementa.000019, 2014.

Godderis, Y., Francois, L., Probst, A., Schott, J., Moncoulon, D., Labat, D., and Viville, D.: Modelling weathering processes at the catchment scale: the WITCH numerical model, Geochim. Cosmochim. Ac., 70, 1128-1147, 2006.

Godsey, S. E., Kirchner, J. W., and Clow, D. W.: Concentrationdischarge relationships reflect chemostatic characteris- tics of US catchments, Hydrol. Process., 23, 1844-1864, doi:10.1002/hyp.7315, 2009.

Graham, C. and Lin, H. S.: Controls and frequency of preferential flow occurrence: a 175-event analysis, Vadose Zone J., 10, 816831, 2011.

Graham, C. G. and Lin, H. S.: Spatial-temporal patterns of preferential flow occurrence in the Shale Hills CZO based on real-time soil moisture monitoring, Vadose Zone J., special issue, 10, 816831, doi:10.2136/vzj2010.0119, 2010.

Guo, L., Chen, J., and Lin, H.: Subsurface lateral flow network on a hillslope revealed by time-lapse ground penetrating radar, Water Resour. Res., 50, 21, 2014.

Hasenmueller, E., Jin, L., Stinchcomb, G., Lin, H., Brantley, S. L., and Kaye, J. P.: Topographic controls on the depth distribution of soil $\mathrm{CO}_{2}$ in a small temperate watershed, Appl. Geochem., 63, 58-69, doi:10.1016/j.apgeochem.2015.07.005, 2015.

Hattanji, T. and Onda, Y.: Coupling of runoff processes and sediment transport in mountainous watersheds underlain by different sedimentary rocks, Hydrol. Process., 18, 623-636, doi:10.1002/hyp.1262, 2004.

Hoekstra, P. and Delaney, A.: Dielectric properties of soils at UHF and microwave frequencies, J. Geophys. Res., 79, 1699-1708, doi:10.1029/JB079i011p01699, 1974.

Homer, C. G., Dewitz, J. A., Yang, L., Jin, S., Danielson, P., Xian, G., Coulston, J., Herold, N. D., Wickham, J. D., and Megown, K.: Completion of the 2011 National Land Cover Database for the conterminous United States-Representing a decade of land cover change information, Photogramm. Eng. Rem. S., 81, 345354, 2015.

Hoover, M. T. and Ciolkosz, E. J.: Colluvial soil parent material relationships in the Ridge and Valley physiographic province of Pennsylvania, Soil Sci., 145, 163-172, 1988.

Jackson, R. B., Anderson, L. J., and Pockman, W. T.: Measuring water availability and uptake in ecosystem studies, Methods in Ecosystem Science, Springer New York, 199-214, doi:10.1007/978-1-4612-1224-9_14, 2000.

Jepsen, S. M., Harmon, T., Meadows, M., and Hunsaker, C.: Hydrogeologic influence on changes in snowmelt runoff with climate warming: Numerical experiments on a mid-elevation catchment in the Sierra Nevada, USA, American Geophysical Union Annual Meeting, San Francisco, USA, 14-18 December 2015, available at: https://agu.confex.com/agu/fm15/meetingapp.cgi/ Paper/70885, 2015.

Jepsen, S. M., Harmon, T. C., and Shi, Y.: Assessment of a watershed model calibrated to the shape of baseflow recession with and without evapotranspiration effects. Water Resources Research, in revision, 2016a.

Jepsen, S. M., Harmon, T. C., Meadows, M. W., and Hunsaker, C. T.: Hydrogeologic influence on changes in snowmelt runoff with climate warming: Numerical experiments on a midelevation catchment in the Sierra Nevada, USA, J. Hydrology, 533, 332-342, doi:10.1016/j.jhydrol.2015.12.010, 2016b.

Jin, L. and Brantley, S. L.: Soil chemistry and shale weathering on a hillslope influenced by convergent hydrologic flow regime at the Susquehanna/Shale Hills Critical Zone Observatory, Appl. Geochem., 26, S51-S56, doi:10.1016/j.apgeochem.2011.03.027, 2011.

Jin, L., Ravella, R., Ketchum, B., Bierman, P. R., Heaney, P., White, T. S., and Brantley, S. L.: Mineral weathering and elemen- 
tal transport during hillslope evolution at the Susquehanna/Shale Hills Critical Zone Observatory, Geochim. Cosmochim. Ac., 74, 3669-3691, 2010.

Jin, L., Andrews, D. M., Holmes, G. H., Lin, H., and Brantley, S. L.: Opening the "black box": water chemistry reveals hydrological controls on weathering in the Susquehanna Shale Hills Critical Zone Observatory, Vadose Zone J., 10, 928-942, doi:10.2136/vzj2010.0133, 2011.

Jin, L., Ogrinc, N., Yesavage, T., Hasenmueller, E. A., Ma, L., Sullivan, P. L., Kaye, J., Duffy, C., and Brantley, S. L.: The $\mathrm{CO}_{2}$ consumption potential during gray shale weathering: insights from the evolution of carbon isotopes in the Susquehanna Shale Hills critical zone observatory, Geochim. Cosmochim. Ac., 142, 260280, doi:10.1016/j.gca.2014.07.006, 2014.

Kaplan, J. O., Bigelow, N. H., Prentice, I. C., Harrison, S. P., Bartlein, P., Christensen, T. R., Cramer, W., Matveyeva, N. V., McGuire, A. D., Murray, D. F., Razzhivin, V. Y., Smith, B., Walker, A. D., Anderson, P. M., Andreev, A. A., Brubaker, L. B., Edwards, M. E., and Lozhkin, A. V.: Climate change and Arctic ecosystems: 2. Modeling, paleodata-model comparisons, amid future projections, J. Geophys. Res., 108, 8171, doi:10.1029/2002JD002559, 2003.

Knyazikhin, Y., Glassy, J., Privette, J. L., Tian, Y., Lotsch, A., Zhang, Y., Wang, Y., Morisette, J. T., Votava, P., Myneni, R. B., Nemani, R. R., and Running, S. W.: MODIS Leaf Area Index (LAI) and Fraction of Photosynthetically Active Radiation Absorbed by Vegetation (FPAR) Product (MOD15) Algorithm, Theoretical Basis Document, NASA Goddard Space Flight Center, Greenbelt, MD 20771, USA, 1999.

Kumar, M., Marks, D., Dozier, J., Reba, M., and Winstral, A.: Evaluation of distributed hydrologic impacts of temperature-index and energy-based snow models, Adv. Water Resour., 56, 77-89, 2013.

Lebedeva, M. and Brantley, S. L.: Exploring geochemical controls on weathering and erosion of convex hillslopes: beyond the empirical regolith production function, Earth Surf. Proc. Land., 38, 1793-1807, doi:10.1002/esp.3424, 2013.

Lebedeva, M. I., Fletcher, R. C., Balashov, V. N., and Brantley, S. L.: A reactive diffusion model describing transformation of bedrock to saprolite, Chem. Geol., 244, 624-645, 2007.

Lebedeva, M. I., Fletcher, R. C., and Brantley, S. L.: A mathematical model for steady-state regolith production at constant erosion rate, Earth Surf. Proc. Land., 35, 508-524, 2010.

Lin, H. S., Kogelmann, W., Walker, C., and Bruns, M. A.: Soil moisture patterns in a forested catchment: A hydropedological perspective, Geoderma 131, 345-368, doi:10.1016/j.geoderma.2005.03.013, 2006.

Lynch, J. A.: Effects of Antecedent Soil Moisture on Storm Hydrographs, Doctor of Philosophy, Forestry, The Pennsylvania State University, University Park, PA, 1976.

Ma, L., Jin, L., and Brantley, S. L.: How mineralogy and slope aspect affect REE release and fractionation during shale weathering in the Susquehanna/Shale Hills Critical Zone Observatory, Chem. Geol., 290, 31-49, 2011.

Ma, L., Chabaux, F., West, N., Kirby, E., Jin, L., and Brantley, S. L.: Regolith production and transport in the Susquehanna Shale Hills Critical Zone Observatory, Part 1: Insights from U-series isotopes, J. Geophys. Res.-Earth, 118, 722-740, doi:10.1002/jgrf.20037, 2013.
Meinzer, F. C., Woodruff, D. R., Eissenstat, D. M., Lin, H. S. Adams, T. S., and McCulloh, K. A.: Above- and belowground controls on water use by trees of different wood types in an eastern US deciduous forest, Tree Physiol., 33, 345-356, 2013.

Merritts, D. J., Walter, R. C., Blair, A., Demitroff, M., Potter Jr., N., Alter, S., Markey, E., Guillorn, S., Gigliotti, S., and Studnicky, C.: LIDAR, orthoimagery, and field analysis of periglacial landforms and their cold climate signature, unglaciated Pennsylvania and Maryland, 2015 GSA Annual Meeting, Baltimore, Maryland, USA, 1-4 November 2015, 47, p. 831, 2015.

Miller, S. R., Sak, P. B., Kirby, E., and Bierman, P. R.: Neogene rejuvenation of central Appalachian topography: evidence for differential rock uplift from stream profiles and erosion rates, Earth Planet. Sc. Lett., 369-370, 13, 2013.

Minasny, B., McBratney, A. B., and Salvador-Blanes, S.: Quantitative models for pedogenesis - a review, Geoderma, 144, 140157, 2008.

Myneni, R. B., Hoffman, S., Knyazikhin, Y., Privette, J. L., Glassy, J., Tian, Y., Wang, Y., Song, X., Zhang, Y., Smith, G. R., Lotsch, A., Friedl, M., Morisette, J. T., Votava, P., Nemani, R. R., and Running, S. W.: Global products of vegetation leaf area and fraction absorbed PAR from year one of MODIS data, Remote Sens. Environ., 83, 214-231, 2002.

Naithani, K. J., Baldwin, D., Gaines, K., Lin, H. S., and Eissenstat, D. M.: Spatial distribution of tree species governs the spatiotemporal interaction of leaf area index and soil moisture across a landscape, PloS ONE, 8, 12, doi:10.1371/journal.pone.0058704, 2013.

Niu, X., Williams, J. Z., Miller, D., Lehnert, K. A., Bills, B., and Brantley, S. L.: An ontology driven relational geochemical database for the Earth's Critical Zone: CZchemDB, J. Environ. Inf., 23, 10-23, doi:10.3808/jei.201400266, 2014.

Portenga, E. W., Bierman, P. R., Rizzo, D. M., and Rood, D. H.: Low rates of bedrock outcrop erosion in the central Appalachian Mountains inferred from in situ Be-10, Geol. Soc. Am. Bull., 125, 201-215, 2013.

Qu, Y. and Duffy, C. J.: A semi-discrete finite volume formulation for multiprocess watershed simulation, Water Resour. Res., 43, 1-18, 2007.

Shi, Y., Davis, K. J., Duffy, C. J., and Yu, X.: Development of a coupled land surface hydrologic model and evaluation at a critical zone observatory, J. Hydrometeorol., 14, 1401-1420, 2013.

Shi, Y., Davis, K. J., Zhang, F., and Duffy, C. J.: Evaluation of the parameter sensitivity of a coupled land surface hydrologic model, J. Hydrometeorol., 15, 279-299, 2014a.

Shi, Y., Davis, K. J., Zhang, F., Duffy, C. J., and Yu, X.: Parameter estimation of a physically-based land surface hydrologic model using the ensemble Kalman Filter: A synthetic experiment, Water Resour. Res., 50, 706-724, doi:10.1002/2013WR014070, 2014b.

Shi, Y., Baldwin, B. C., Davis, K. J., Yu, X., Duffy, C. J., and Lin, H.: Simulating high resolution soil moisture patterns in the Shale Hills catchment using a land surface hydrologic model, Hydrol. Process., doi:10.1002/hyp.10593, 2015a.

Shi, Y., Davis, K. J., Zhang, F., Duffy, C., J., and Yu, X.: Parameter estimation of a physically-based land surface hydrologic model using an ensemble Kalman filter: a multivariate real-data experiment, Adv. Water Resour., 83, 421-427, doi:10.1016/j.advwatres.2015.06.009, 2015b. 
Sullivan, P. L., Hynek, S., Gu, X., Singha, K., White, T. S., West, N., Kim, H., Clarke, B., Kirby, E., Duffy, C., and Brantley, S. L.: Oxidative dissolution under the channel leads geomorphological evolution at the Shale Hills catchment, Am. J. Sci., submitted, 2016.

Tarboton, D. G.: A new method for the determination of flow directions and upslope areas in grid digital elevation models, Water Resour. Res., 33, 309-319, doi:10.1029/96WR03137, 1997.

Thomas, E., Lin, H., Duffy, C., Sullivan, P., Holmes, G. H., Brantley, S. L., and Jin, L.: Spatiotemporal patterns of water stable isotope compositions at the Shale Hills Critical Zone: linkages to subsurface hydrologic processes, Vadose Zone J., 12, doi:10.2136/vzj2013.01.0029, 2013.

Topp, G. and Ferre, P.-A.: Water content, in: Method of soil analysis, Part 4, Physical methods, SSSA Book, 5th Edn., edited by: Dane, J. H. and Topp, G. C., Soil Sci. Soc. of Am., Madison, Wis., 417-446, 2002.

Topp, G., Davis, J. L., and Annan, A. P.: Electromagnetic determination of soil water content: Measurement in coaxial transmission lines, Water Resour. Res., 16, 574-582, 1980.

Vitousek, P. M., Aber, J. D., Horwath, R. W., Lubchenco, J., and Melillo, J. M.: Human alteration of the global nitrogen cycle, Science, 277, 494-499, 1997a.

Vitousek, P. M., Mooney, H. A., Lubchenco, J., and Melillo, J. M.: Human domination of Earth's ecosystems, Science, 277, 494499, 1997b.

Wang, R., Kumar, M., and Marks, D.: Anomalous trend in soil evaporation in a semi-arid, snow-dominated watershed, Adv. Water Resour., 57, 32-40, 2013.

Warnant, P., Francois, L., Strivay, D., and Gerard, J.-C.: CARAIB: a global model of terrestrial biological productivity, Global Biogeochem. Cy., 8, 255-270, 1994.

West, N., Kirby, E., Bierman, P. R., Slingerland, R., Ma, L., Rood, D., and Brantley, S. L.: Regolith production and transport at the Susquehanna Shale Hills Critical Zone Observatory: Part 2 - Insights from meteoric 10Be. J. Geophys. Res.-Earth, 118, 1-20, doi:10.1002/jgrf.20121, 2013.

West, N., Kirby, E., Bierman, P. R., and Clarke, B. A.: Aspectdependent variations in regolith creep revealed by meteoric 10Be, Geology, 42, 507-510, doi:10.1130/G35357.1, 2014.

Whipple, K. X., Dibiase, R. A., and Crosby, B. T.: Bedrock rivers, in: Treatise in Geomorphology, Fluvial Geomorphology, edited by: Wohl, E., Academic Press, San Diego, CA, 550-573, doi:10.1016/B978-0-12-374739-6.00254-2, 2013.
White, T., Brantley, S., Banwart, S., Chorover, J., Dietrich, W., Derry, L., Lohse, K., Anderson, S., Aufdendkampe, A., Bales, R., Kumar, P., Richter, D., and McDowell, B.: The Role of Critical Zone Observatories in Critical Zone Science, in: Developments in Earth Surface Processes 19, Principles and Dynamics of the Critical Zone, edited by: Giardino, J. and Houser, C., Elsevier, 15-78, 2015.

Wilkinson, B. H. and McElroy, B. J.: The impact of humans on continental erosion and sedimentation, Geol. Soc. Am. Bull., 119, 140-156, 2007.

Willett, S. D., McCoy, S. W., Perron, J. T., Goren, L., and Chen, C. Y.: Dynamic reorganization of river basins, Science, 343, 1-9, doi:10.1126/science.1248765, 2014.

Williams, J., Reynolds, R., Franzi, D., Romanowics, E., and Paillet, F.: Hydrogeology of the Potsdam sandstone in northern New York, Can. Water Resour. J., 35, 399-415, 2010.

Williard, K., Dewalle, D., and Edwards, P.: Influence of bedrock geology and tree species composition on stream nitrate concentrations in mid-Appalachian forested watersheds, Water Air Soil Poll., 160, 55-76, 2005.

Yu, X., Lamačová, A., Duffy, C., Krám, P., Hruška, J., White, T., and Bhatt, G.: Modelling long-term water yield effects of forest management in a Norway spruce forest, Hydrol. Sci. J., 60, 174191, doi:10.1080/02626667.2014.897406, 2015.

Zhang, J., Lin, H. S., and Doolittle, J.: Soil layering and preferential flow impacts on seasonal changes of GPR signals in two contrasting soils, Geoderma, 213, 560-569, doi:10.1016/j.geoderma.2013.08.035, 2014.

Zhu, Q., Lin, H., and Doolittle, J.: Repeated electromagnetic induction surveys for determining subsurface hydrologic dynamics in an agricultural landscape, Soil Sci. Soc. Am. J., 74, 12, 2010 a.

Zhu, Q., Lin, H., and Doolittle, J.: Repeated electromagnetic induction surveys for improved soil mapping in an agricultural landscape, Soil Sci. Soc. Am. J., 74, 1763-1774, doi:10.2136/sssaj2010.0056, 2010b.

Zreda, M., Shuttleworth, W. J., Zeng, X., Zweck, C., Desilets, D., Franz, T., and Rosolem, R.: Corrigendum to "COSMOS: the COsmic-ray Soil Moisture Observing System" published in Hydrol. Earth Syst. Sci., 16, 4079-4099, 2012, Hydrol. Earth Syst. Sci., 17, 1065-1066, doi:10.5194/hess-17-1065-2013, 2013.

Zweck, C., Zreda, M., and Desilets, D.: Snow shielding factors for cosmogenic nuclide dating inferred from Monte Carlo neutron transport simulations, Earth Planet. Sc. Lett., 379, 64-71, 2013. 